Radionuclides, Stable Isotopes, Inorganic Constituents, and Organic Compounds in Water from Selected Wells and Springs from the Southern Boundary of the Idaho National Engineering Laboratory to the Hagerman Area, Idaho, 1995

By ROY C. BARTHOLOMAY and LINDA M. WILLIAMS, U.S. GEOLOGICAL SURVEY, and LINFORD J. CAMPBELL, IDAHO DEPARTMENT OF WATER RESOURCES

U.S. GEOLOGICAL SURVEY

Open-File Report 96-496

Prepared in cooperation with the U.S. DEPARTMENT OF ENERGY and IDAHO DEPARTMENT OF WATER RESOURCES

Idaho Falls, Idaho

September 1996

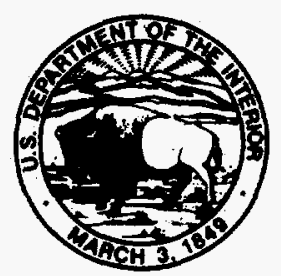




\section{U.S. DEPARTMENT OF THE INTERIOR \\ BRUCE BABBITT, Secretary \\ U.S. GEOLOGICAL SURVEY \\ GORDON P. EATON, Director}

Any use of trade, product, or firm names is for descriptive purposes

only and does not imply endorsement by the U.S. Government.

For additional information write to:

U.S. Geological Survey

INEL, MS 4148

P.O. Box 2230

Idaho Falls, ID 83403
Copies of this report can be purchased from:

U.S. Geological Survey

Branch of Information Services

Box 25286

Denver, CO 80225-0286 


\section{DISCLAMMER}

Portions of this document may be illegible in electronic image products. Images are produced from the best available original docoment. 


\section{CONTENTS}

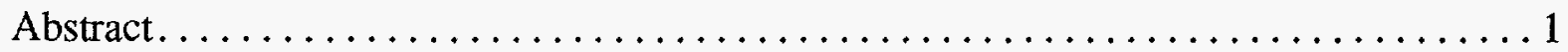

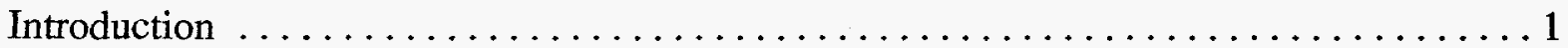

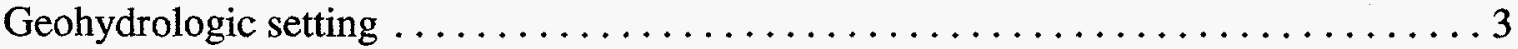

Acknowledgments ....................................... 3

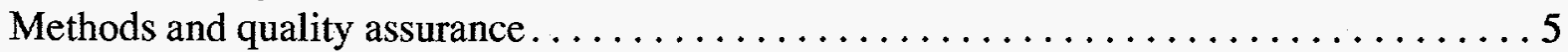

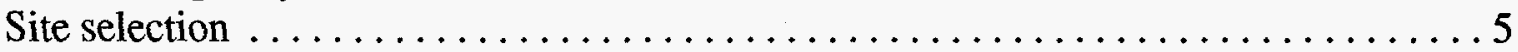

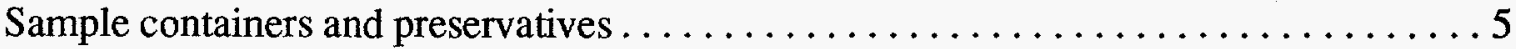

Sample collection. . . . . . . . . . . . . . . . . . . . . . . . . . . . . . . 5

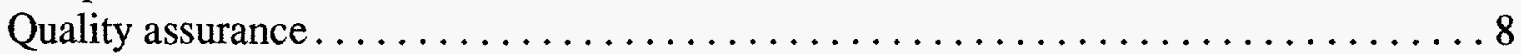

Radionuclides ......................................... 8

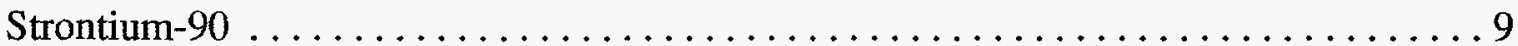

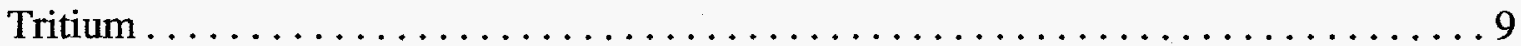

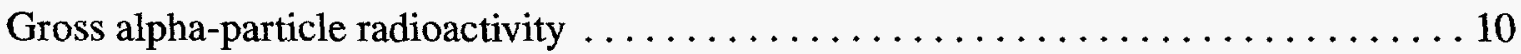

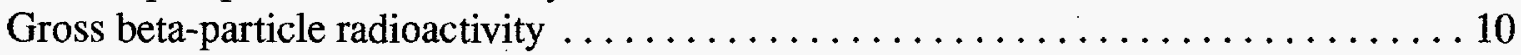

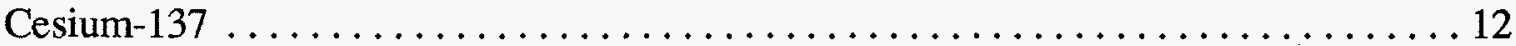

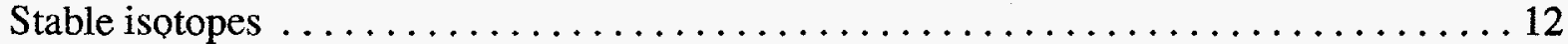

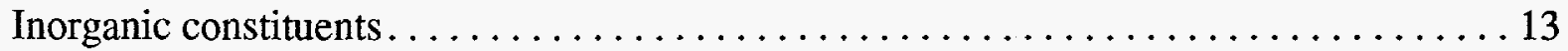

Trace elements . . . . . . . . . . . . . . . . . . . . . . . . . . . . 13

Common ions. . . . . . . . . . . . . . . . . . . . . . . . . . . . . . . 19

Nutrients............................................. 19

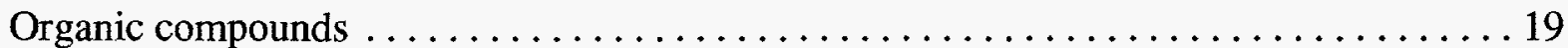

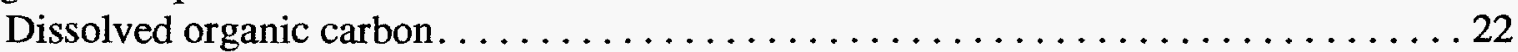

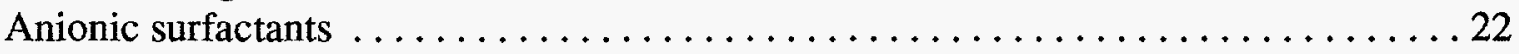

Purgeable organic compounds ................................ 22

Insecticides and gross polychlorinated compounds $\ldots \ldots \ldots \ldots \ldots \ldots \ldots \ldots \ldots 22$

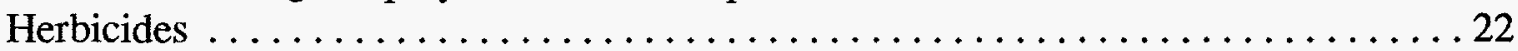

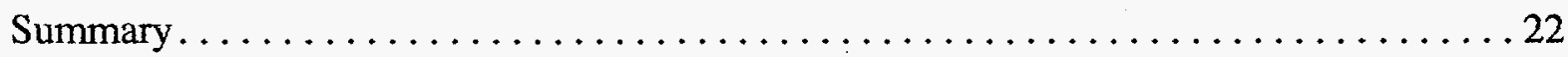

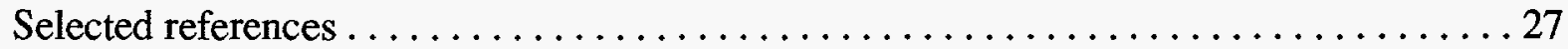

\section{FIGURES}

Figures 1-2. Maps showing:

1. Location of the study area, between the Idaho National Engineering

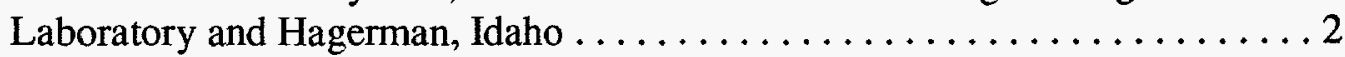

2. Location of selected water-quality sampling sites on the eastern Snake River Plain.

\section{TABLES}

Table 1. Containers and preservatives used for water-sample collection. ...........6 6

2. Results of field measurements of water for $\mathrm{pH}$, specific conductance, temperature, alkalinity, and dissolved oxygen from selected wells and springs, eastern Snake River Plain . . ........................ 7

3. Maximum contaminant levels for types of radioactivity and selected radionuclides in drinking water. 
4. Concentrations of strontium-90 and tritium in water from selected wells and

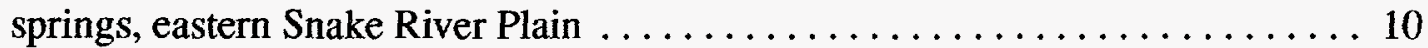

5. Concentrations of gross alpha-particle radioactivity in water from selected wells and springs, eastern Snake River Plain . . . . . . . . . . . 11

6. Concentrations of gross beta-particle radioactivity in water from selected

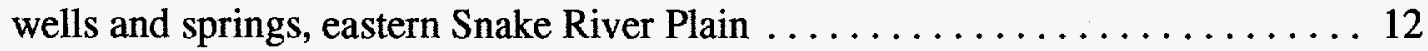

7. Concentrations of cesium-137 in water from selected wells and springs, eastern Snake River Plain . . . . . . . . . . . . . . . . . . . . . 13

8. Relative concentrations of stable isotopes in water from selected wells and springs, eastern Snake River Plain . . . . . . . . . . . . . . . 14

9. Maximum contaminant levels and minimum reporting levels of selected trace

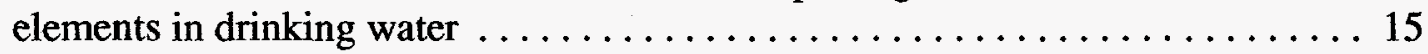

10. Concentrations of dissolved trace elements and hexavalent and total chromium in water from selected wells and springs, eastern Snake River Plain . . . . . . . 16

11. Maximum contaminant levels and minimum reporting levels of selected common ions in drinking water. ......................... 20

12. Concentrations of dissolved common ions in water from selected wells and

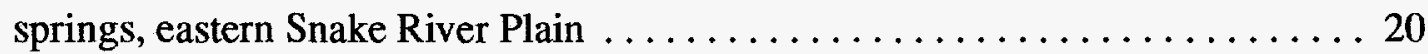

13. Maximum contaminant levels and minimum reporting levels of selected nutrients, dissolved organic carbon, and anionic surfactants in drinking water . . 21

14. Concentrations of nutrients, dissolved organic carbon, and anionic surfactants in water from selected wells and springs, eastern Snake River Plain . . . . . . . 21

15. Maximum contaminant levels and minimum reporting levels of selected purgeable organic compounds in drinking water $\ldots \ldots \ldots \ldots \ldots \ldots \ldots$

16. Maximum contaminant levels and minimum reporting levels of selected insecticides and gross polychlorinated compounds in drinking water . . . . . 24

17. Maximum contaminant levels and minimum reporting levels of chlorophenoxy-acid herbicides and other herbicides in drinking water . . . . . 25

18. Concentrations of herbicides in water from selected wells and springs, eastern Snake River Plain . . . . . . . . . . . . . . . . . . 26

\section{CONVERSION FACTORS AND ABBREVIATED UNITS}

\begin{tabular}{rcl}
\hline Multiply & By & To Obtain \\
\hline acre-foot per year (acre-ft/yr) & 1,233 & cubic meter per year \\
foot $(\mathrm{ft})$ & 0.3048 & meter \\
gallon $(\mathrm{gal})$ & 3.785 & liter \\
mile $(\mathrm{mi})$ & 1.609 & kilometer \\
millirem per year (mrem/yr) & 0.010 & millisievert per year \\
picocurie per liter $(\mathrm{pCi} / \mathrm{L})$ & 0.037 & becquerel per liter \\
square mile $\left(\mathrm{mi}^{2}\right)$ & 2.590 & square kilometer \\
\end{tabular}

Temperature can be converted from degrees Celsius $\left({ }^{\circ} \mathrm{C}\right)$ to degrees Fahrenheit $\left({ }^{\circ} \mathrm{F}\right)$ by the equation: ${ }^{\circ} \mathrm{F}=\left({ }^{\circ} \mathrm{C} \times 1.8\right)+32$.

Abbreviated units used in report: $\mathrm{mL}$ (milliliter); $\mathrm{L}$ (liter); $\mu g / \mathrm{L}$ (microgram per liter); $\mathrm{mg} / \mathrm{L}$ (milligram per liter); $\mu \mathrm{m}$ (micrometer); and $\mu \mathrm{S} / \mathrm{cm}$ (microsiemens per centimeter) at 25 degrees Celsius. 


\title{
Radionuclides, Stable Isotopes, Inorganic Constituents, and Organic Compounds in Water from Selected Wells and Springs from the Southern Boundary of the Idaho National Engineering Laboratory to the Hagerman Area, Idaho, 1995
}

\author{
By Roy C. Bartholomay and Linda M. Williams, U.S. Geological Survey, and \\ Linford J. Campbell, Idaho Department of Water Resources
}

\section{Abstract}

The U.S. Geological Survey and the Idaho Department of Water Resources, in cooperation with the U.S. Department of Energy, sampled 17 sites as part of a long-term project to monitor water quality of the Snake River Plain aquifer from the southern boundary of the Idaho National Engineering Laboratory to the Hagerman area. Water samples were collected and analyzed for selected radionuclides, stable isotopes, inorganic constituents, and organic compounds. The samples were collected from 11 irrigation wells, 2 domestic wells, 2 stock wells, 1 spring, and 1 public-supply well. Two quality assurance samples also were collected and analyzed.

None of the radionuclide, inorganic constituent, or organic compound concentrations exceeded the established maximum contaminant levels for drinking water. Many of the radionuclide and inorganic constituent concentrations were greater than their respective reporting levels. All samples analyzed for dissolved organic carbon had concentrations that were greater than the minimum reporting level.

\section{INTRODUCTION}

Recently, the public has expressed concern about waste disposal practices at the Idaho National Engineering Laboratory (INEL) and the effect these practices might have had on the water quality of the Snake River Plain aquifer. The U.S. Department of Energy (DOE) requested that the
U.S. Geological Survey (USGS) conduct two studies to respond to the public's concem and to gain a greater understanding of the chemical quality of water in the aquifer. The first study described a one-time sampling effort in the eastern part of the A \& B Irrigation District in Minidoka County (Mann and Knobel, 1990). The second study, an ongoing annual sampling effort in the area between the southern boundary of the INEL and Hagerman (fig. 1), is being conducted in cooperation with the Idaho Department of Water Resources (IDWR) and the DOE. The initial round of sampling for the second study involved analyzing water samples collected from 55 sites during August and September 1989 (Wegner and Campbell, 1991). The second round of sampling involved analyzing water samples collected from 19 of the initial 55 sites in 1990 (Bartholomay and others, 1992), another 18 of the initial 55 sites in 1991 (Bartholomay and others, 1993), and the remaining 18 sites in 1992 (Bartholomay and others, 1994a). The third round of sampling involved analyzing water samples collected from 19 of the initial 55 sites in 1993 (Bartholomay and others, 1994b), and 18 more of the initial 55 sites during 1994 (Bartholomay and others, 1995). This report summarizes the analyses of water samples collected as part of the third round in June-July 1995 from 17 more of the initial 55 sites. One site was not sampled because the pump was not operating and will be sampled at the beginning of the 1996 sample period. 


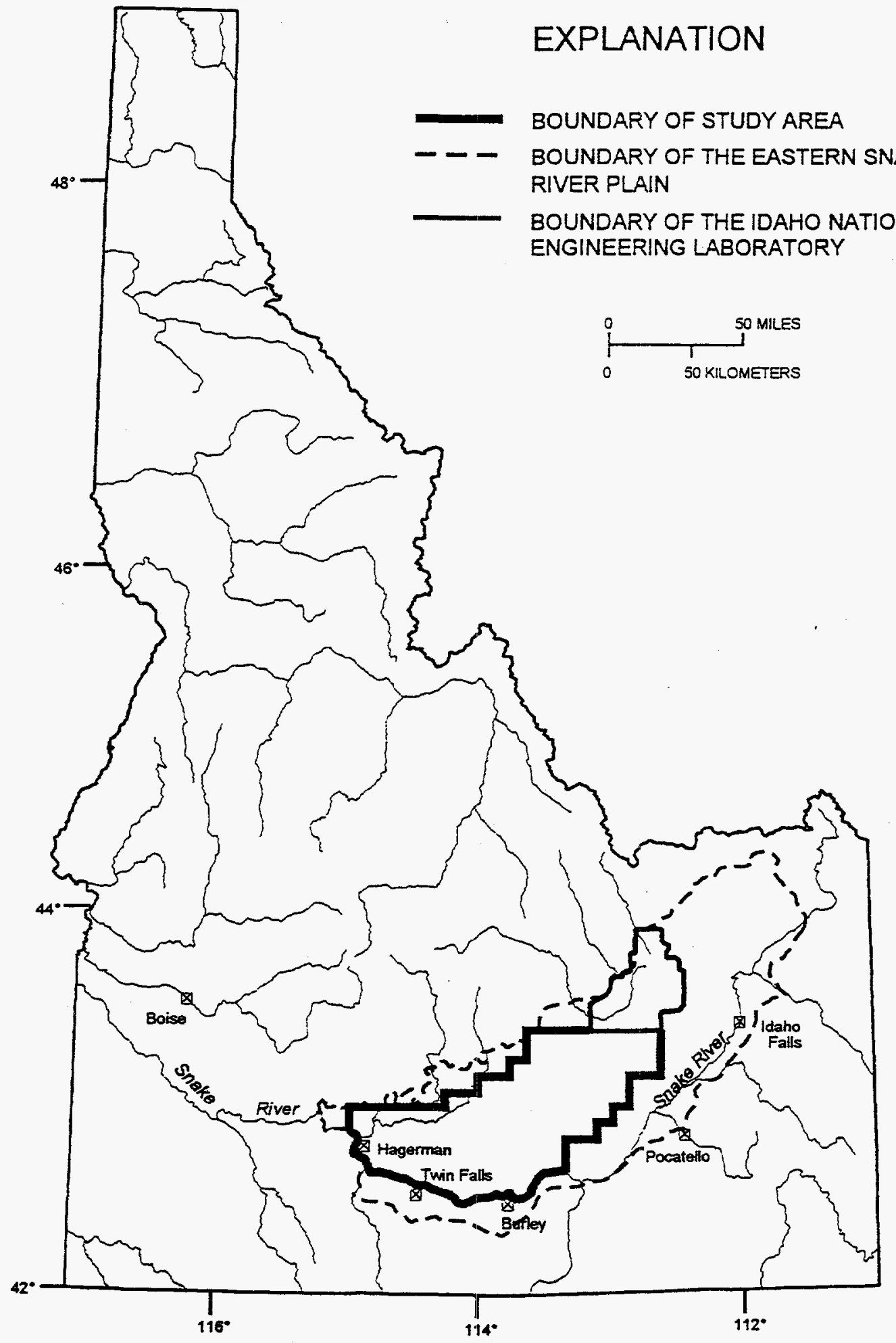

Figure 1. Location of the study area, between the Idaho National Engineering Laboratory and Hagerman, Idaho. 
The INEL includes about $890 \mathrm{mi}^{2}$ of the northeastern part of the eastern Snake River Plain and is about 110 mi northeast of the Hagerman area (fig. 1). In the past, wastewater containing chemical and radiochemical wastes generated at the INEL was discharged mostly to ponds and wells. Since 1983, most aqueous wastes have been discharged to infiltration ponds. Many of the constituents in the wastewater enter the aquifer indirectly following percolation through the unsaturated zone (Pittman and others, 1988).

Chemical and radioactive wastes have migrated from less than 1 to about $9 \mathrm{mi}$ southwest of the disposal areas at the INEL (Pittman and others, 1988). Tritium was detected intermittently at concentrations of $3,400 \pm 200 \mathrm{pCi} / \mathrm{L}$ or less in water from three wells along the southern boundary of the INEL between 1983 and 1985. Since 1985, tritium concentrations in water from wells near the southern boundary of the INEL have been less than the reporting level (Bartholomay and others, 1995, p. 22).

Water samples from 17 sites (fig. 2) were analyzed for selected radionuclides, stable isotopes, trace elements, common ions, nutrients, dissolved organic carbon (DOC), anionic surfactants as methylene blue active substances (MBAS), purgeable organic compounds, carbamate insecticides, organophosphate insecticides, organochlorine insecticides, gross polychlorinated biphenyls (PCB's), gross polychlorinated naphthalenes (PCN's), chlorophenoxy-acid herbicides, and other herbicides by the USGS National Water Quality Laboratory (NWQL) at Arvada, Colo. Samples also were collected at the same sites for analyses of selected radionuclides by the Idaho State University (ISU) Environmental Monitoring Laboratory in Pocatello, Idaho. Two replicate water samples also were collected and analyzed as a measure of quality assurance.

\section{Geohydrologic Setting}

The eastern Snake River Plain is a northeasttrending structural basin about $200 \mathrm{mi}$ long and 50 to $70 \mathrm{mi}$ wide. The basin, bounded by faults on the northwest and downwarping and faulting on the southeast, has been filled with basaltic lava flows interbedded with terrestrial sediments
(Whitehead, 1986). Individual basalt flows average 20 to $25 \mathrm{ft}$ in thickness with an aggregate thickness of several thousand feet in places. Alluvial fan deposits are composed primarily of sand and gravel, whereas in areas where streams were dammed by basalt flows, the sediments are predominantly silt and clay (Garabedian, 1986). Rhyolitic lava flows and tuffs are exposed locally at the surface and may exist at depth under most of the eastern plain. A 10,365-ft-deep test hole at the INEL penetrated about $2,160 \mathrm{ft}$ of basalt and sediment and $8,205 \mathrm{ft}$ of tuffaceous and rhyolitic volcanic rocks (Mann, 1986).

Movement of water in the aquifer generally is from the northeast to the southwest. Water moves horizontally through basalt interflow zones and vertically through joints and interfingering edges of the interflow zones. Infiltration of surface water, heavy pumpage, geologic conditions, and seasonal fluxes of recharge and discharge locally affect the movement of ground water (Garabedian, 1986).

The Snake River Plain aquifer is recharged by seepage from the upper reaches of the Snake River, tributaries and canals, infiltration from irrigation and precipitation, and underflow from tributary valleys on the perimeter of the plain. Discharge from the aquifer primarily is by pumpage for irrigation and spring flow to the Snake River (Mann and Knobel, 1990). Between 1902 and 1980, spring flow to the Snake River increased from about 3.1 million to about 4.3 million acre- $\mathrm{ft} / \mathrm{yr}$, largely as a result of increased recharge from infiltration of irrigation water (Kjelstrom, 1992, fig. 27).

\section{Acknowledgments}

The authors gratefully acknowledge the well owners for granting permission to collect the water samples and extend special thanks to Dale Connell of the Shoshone District of the Bureau of Land Management for his help in locating and pumping two of the wells for sample collection. The authors are grateful for technical review of the manuscript by Ivalou O'Dell and Donald $L$. Boyce of the USGS. 


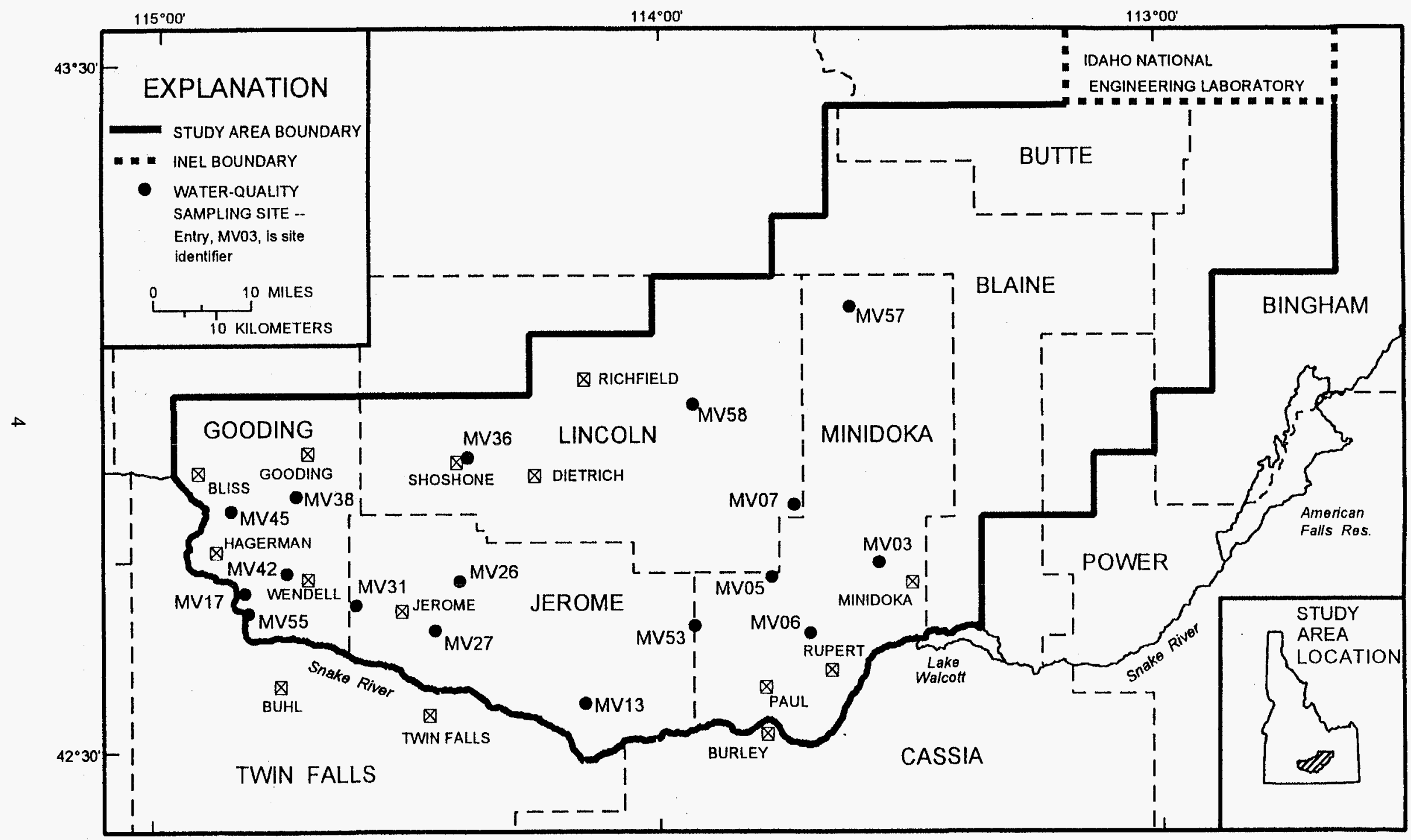

Figure 2.-- Location of selected water-quality sampling sites on the eastern Snake River Plain. 


\section{METHODS AND QUALITY ASSURANCE}

The methods used in sampling and analyzing for selected chemicals generally followed the guidelines established by the USGS (Goerlitz and Brown, 1972; Stevens and others, 1975; Wood, 1981; Claassen, 1982; W.L. Bradford, USGS, written commun., 1985; Wershaw and others, 1987; Fishman and Friedman, 1989; Faires, 1992; and Fishman, 1993). The methods used in the field and quality assurance practices are outlined in the following sections.

\section{Site Selection}

Water samples were collected at 17 sites (fig. 2 ), including 11 irrigation wells, 2 domestic wells, 2 stock wells, 1 spring, and 1 public-supply well. Two quality assurance water samples also were collected. The irrigation wells were equipped with turbine pumps. The domestic, stock, and publicsupply wells were equipped with submersible pumps. Criteria for site selection were geographic location, ease of sample collection, and long-term access.

\section{Sample Containers and Preservatives}

Sample containers and preservatives differ depending on the constituent(s) for which analyses are requested. Samples analyzed by the NWQL were collected and preserved in accordance with laboratory requirements specified by Timme (1995). Water samples analyzed by ISU were collected in accordance with laboratory requirements specified by the Director of the Environmental Monitoring Program at ISU. Containers and preservatives were supplied by the respective laboratories. Containers and preservatives used for this study are listed on table 1.

\section{Sample Collection}

Four of the irrigation wells discharged into stilling ponds or canals and were sampled from the discharge pipe. The remaining irrigation wells were sampled from spigots in discharge lines near pumps; domestic, stock, and public-supply wells were sampled from spigots closest to pumps. All the wells either were pumping on arrival of the sampling team or were started on arrival and pumped long enough to ensure that pressure tanks and pumping systems had been thoroughly flushed as evidenced by stable $\mathrm{pH}$, specific conductance, and water temperature measurements. The spring was sampled near the USGS gaging station by collecting a grab sample from an area of moving water.

Chemical and physical characteristics monitored at the water-sampling sites included $\mathrm{pH}$, specific conductance, water temperature, alkalinity, and dissolved oxygen. These characteristics were monitored during pumping using methods described by Wood (1981) and Hardy and others (1989). A water sample was collected when measurements of these characteristics indicated probable hydraulic and chemical stability. After collection, sample containers were sealed with laboratory film, labeled, and packed into ice chests for shipment by overnight-delivery mail to the NWQL. The samples collected for ISU were stored in coolers until they were hand-delivered to the laboratory.

Measurements of $\mathrm{pH}$, specific conductance, water temperature, alkalinity, and dissolved oxygen are shown on table 2. Measured $\mathrm{pH}$ of water from sampling sites ranged from 7.5 to 8.3 , which is within the U.S. Environmental Protection Agency's (1994) recommended range of 6.5 to 8.5 for community water systems. Specific conductance measurements ranged from 256 to 820 $\mu \mathrm{S} / \mathrm{cm}$. Measurements of water temperature ranged from 11.5 to $16.0^{\circ} \mathrm{C}$. The Idaho Department of Health and Welfare (IDHW) (1989) has established a secondary maximum contaminant level of $26.6^{\circ} \mathrm{C}$ for water temperature. Alkalinity as calcium carbonate ranged from 99 to 213 $\mathrm{mg} / \mathrm{L}$. Dissolved oxygen ranged from 6.6 to $9.8 \mathrm{mg} / \mathrm{L}$.

Conditions at the sampling site during sample collection were recorded in a field logbook; a chain-of-custody record was used to track the samples from the time of collection until delivery to the analyzing laboratory. These records are available for inspection at the USGS Project Office at the INEL. 
Table 1. Containers and preservatives used for water-sample collection

[Abbreviations: $\mathrm{L}$, liter, ${ }^{\circ} \mathrm{C}$, degrees Celsius; $\mathrm{mL}$, milliliter; $\mu \mathrm{m}$, micrometer; gal, gallon. Chemical formulas: $\mathrm{HNO}_{3}$, nitric acid; $\mathrm{K}_{2} \mathrm{Cr}_{2} \mathrm{O}_{7}$, potassium dichromate; $\mathrm{SrCl}_{2}$, strontium chloride. Chilled samples were shipped by ovemight-delivery mail. Analyzing laboratory: NWQL, U.S. Geological Survey National Water Quality Laboratory; ISU, Idaho State University Environmental Monitoring Laboratory]

\begin{tabular}{|c|c|c|c|c|c|c|}
\hline \multirow{2}{*}{$\begin{array}{l}\text { Constituent or type of } \\
\text { constituent }\end{array}$} & \multicolumn{2}{|l|}{ Container } & \multicolumn{2}{|c|}{ Preservative } & \multirow[b]{2}{*}{ Other treatment } & \multirow{2}{*}{$\begin{array}{l}\text { Analyzing } \\
\text { laboratory }\end{array}$} \\
\hline & Type & Size & Type & Size & & \\
\hline Strontium-90 & Polyethylene, acid rinsed & $1 \mathrm{~L}$ & $\mathrm{HNO}_{3}$ & $4 \mathrm{~mL}$ & $0.45-\mu \mathrm{m}$ filter & NWQL \\
\hline \multirow[t]{2}{*}{ Tritium } & Polyethylene & $1 \mathrm{~L}$ & None & None & None & NWQL \\
\hline & Polyethylene & $1 \mathrm{~L}$ & None & None & None & ISU \\
\hline \multirow[t]{2}{*}{ Other radionuclides } & Polyethylene, acid rinsed & $1 \mathrm{~L}$ & $\mathrm{HNO}_{3}$ & $4 \mathrm{~mL}$ & $.45-\mu \mathrm{m}$ filter & NWQL \\
\hline & Polyethylene & $1 \mathrm{gal}$ & None & None & None & ISU \\
\hline \multicolumn{7}{|l|}{ Stable isotopes for: } \\
\hline Carbon & Glass, baked & $1 \mathrm{~L}$ & Ammoniacal $\mathrm{SrCl}_{2}$ & $50 \mathrm{~mL}$ & None & NWQL \\
\hline Nitrogen & Glass, baked & $1 \mathrm{~L}$ & None & None & Chill $4^{\circ} \mathrm{C}$ & NWQL \\
\hline Sulfur & Polyethylene & $1 \mathrm{~L}$ & None & None & None & NWQL \\
\hline Hydrogen and oxygen & Glass & $60 \mathrm{~mL}$ & None & None & None & NWQL \\
\hline \multirow[t]{2}{*}{ Trace elements } & Polyethylene, acid rinsed & $250 \mathrm{~mL}$ & $\mathrm{HNO}_{3}$ & $1 \mathrm{~mL}$ & $.45-\mu \mathrm{m}$ filter & NWQL \\
\hline & Polyethylene & $125 \mathrm{~mL}$ & None & None & None & NWQL \\
\hline Mercury & Glass, acid rinsed & $250 \mathrm{~mL}$ & $\mathrm{HNO}_{3} / \mathrm{K}_{2} \mathrm{Cr}_{2} \mathrm{O}_{7}$ & $10 \mathrm{~mL}$ & $.45-\mu \mathrm{m}$ filter & NWQL \\
\hline \multirow[t]{4}{*}{ Common ions } & Polyethylene, acid rinsed & $500 \mathrm{~mL}$ & $\mathrm{HNO}_{3}$ & $2 \mathrm{~mL}$ & $.45-\mu \mathrm{m}$ filter & NWQL \\
\hline & Polyethylene, acid rinsed & $500 \mathrm{~mL}$ & $\mathrm{HNO}_{3}$ & $2 \mathrm{~mL}$ & None & NWQL \\
\hline & Polyethylene & $250 \mathrm{~mL}$ & None & None & $.45-\mu \mathrm{m}$ filter & NWQL \\
\hline & Polyethylene & $250 \mathrm{~mL}$ & None & None & None & NWQL \\
\hline Nutrients & Polyethylene, brown & $125 \mathrm{~mL}$ & None & None & $.45-\mu \mathrm{m}$ filter, chill $4^{\circ} \mathrm{C}$ & NWQL \\
\hline Dissolved organic carbon & Glass, baked & $125 \mathrm{~mL}$ & None & None & Silver filter, chill $4^{\circ} \mathrm{C}$ & NWQL \\
\hline Anionic surfactants & Polyethylene & $250 \mathrm{~mL}$ & None & None & Chill $4^{\circ} \mathrm{C}$ & NWQL \\
\hline Purgeable organic compounds & Glass, baked & $40 \mathrm{~mL}$ & None & None & Chill $4^{\circ} \mathrm{C}$ & NWQL \\
\hline Pesticides & Glass, baked & $1 \mathrm{~L}$ & None & None & Chill $4^{\circ} \mathrm{C}$ & NWQL \\
\hline
\end{tabular}


Table 2. Results of field measurements of water for $\mathrm{pH}$, specific conductance, temperature, alkalinity, and dissolved oxygen from selected wells and springs, eastern Snake River Plain

[See figure 2 for location of sites. Site type: 1, irrigation; Sp, spring; $P$, public supply; $H$, domestic; QA, quality assurance (MV-44 is a replicate of MV-38; MV-60 is a replicate of MV-55); S, stock. Date sampled: month/day/year. Units: $\mathrm{pH}$, negative base-10 logarithm of hydrogen ion activity in moles per liter, specific conductance, microsiemens per centimeter at $25^{\circ} \mathrm{C}$ (degrees Celsius); temperature, ${ }^{\circ} \mathrm{C}$; alkalinity, milligrams per liter (mg/L) as calcium carbonate using digital titration with $0: 16$ normal sulfuric acid; dissolved oxygen, $\mathrm{mg} / \mathrm{L}$ using azide modification of Winkler method (American Public Health Association and Water Pollution Control Federation, 1985)]

\begin{tabular}{|c|c|c|c|c|c|c|c|}
\hline $\begin{array}{c}\text { Site } \\
\text { identifier }\end{array}$ & Site type & $\begin{array}{c}\text { Date } \\
\text { sampled }\end{array}$ & $\mathrm{pH}$ & $\begin{array}{c}\text { Specific } \\
\text { conductance }\end{array}$ & Temperature & Alkalinity & $\begin{array}{l}\text { Dissolved } \\
\text { oxygen }\end{array}$ \\
\hline MV-03 & I & $7 / 25 / 95$ & 7.8 & 441 & 12.5 & 126 & 8.3 \\
\hline MV-05 & I & $7 / 25 / 95$ & 7.8 & 696 & 12.0 & 166 & 8.3 \\
\hline MV-06 & I & $7 / 25 / 95$ & 7.5 & 629 & 14.0 & 207 & 6.6 \\
\hline MV-07 & I & $6 / 20 / 95$ & 7.8 & 353 & 13.0 & 117 & 7.9 \\
\hline MV-13 & I & $7 / 27 / 95$ & 7.6 & 611 & 15.0 & 188 & 7.8 \\
\hline MV-17 & $\mathrm{Sp}$ & $7 / 24 / 95$ & 8.0 & 409 & 14.5 & 129 & 8.7 \\
\hline MV-26 & I & $7 / 25 / 95$ & 7.8 & 467 & 14.0 & 133 & 8.3 \\
\hline MV-27 & I & $7 / 31 / 95$ & 7.6 & 678 & 14.5 & 174 & 8.0 \\
\hline MV-31 & I & $7 / 24 / 95$ & 7.9 & 630 & 14.0 & 160 & 8.2 \\
\hline MV-36 & $\mathrm{P}$ & $7 / 26 / 95$ & 7.7 & 424 & 13.5 & 184 & 9.0 \\
\hline MV-38 & I & $7 / 24 / 95$ & 7.8 & 368 & 14.0 & 151 & 7.9 \\
\hline MV-42 & $\mathrm{H}$ & $7 / 26 / 95$ & 7.7 & 440 & 15.0 & 160 & 7.8 \\
\hline MV-44 & QA & $7 / 24 / 95$ & 7.8 & 368 & 14.0 & 151 & 7.9 \\
\hline MV-45 & I & $6 / 20 / 95$ & 8.0 & 368 & 15.5 & 137 & 7.9 \\
\hline MV-53 & $\mathrm{H}$ & $7 / 26 / 95$ & 7.7 & 820 & 16.0 & 213 & 8.9 \\
\hline MV-55 & I & $7 / 26 / 95$ & 7.7 & 420 & 14.5 & 132 & 8.4 \\
\hline MV-57 & $S$ & $6 / 29 / 95$ & 7.9 & 256 & 12.0 & 99 & 8.2 \\
\hline MV-58 & $S$ & $6 / 29 / 95$ & 8.3 & 279 & 11.5 & 116 & 9.8 \\
\hline MV-60 & QA & $7 / 26 / 95$ & 7.7 & 420 & 14.5 & 132 & 8.4 \\
\hline
\end{tabular}


Table 3. Maximum contaminant levels for types of radioactivity and selected radionuclides in drinking water [The maximum contaminant levels were established pursuant to the recommendations of the U.S. Environmental Protection Agency (1995, p. 913) for community water systems and are included for comparison purposes only. Maximum contaminant levels given for strontium-90 and tritium are average annual concentrations assumed to produce a total body or organ dose of $4 \mathrm{mrem} / \mathrm{yr}$ (millirem per year) of beta-particle radiation. The maximum contaminant level given for gross alpha-particle radioactivity includes radium-226 but excludes radon and uranium. The maximum contaminant level given for gross beta-particle and gamma radioactivity excludes radioactivity from natural sources and is included for comparison purposes only. Abbreviation: pCil, picocurie per liter]

\begin{tabular}{lc}
\hline \multicolumn{1}{c}{ Type of radioactivity or radionuclide } & Maximum contaminant level \\
\hline Strontium- 90 & $8 \mathrm{pCi} / \mathrm{L}$ \\
Tritium & $20,000 \mathrm{pCi} / \mathrm{L}$ \\
Gross alpha-particle radioactivity & $15 \mathrm{pCi} / \mathrm{L}$ \\
Gross beta-particle and gamma radioactivity & $4 \mathrm{mrem} / \mathrm{yr}$ \\
\hline
\end{tabular}

\section{Quality Assurance}

Detailed descriptions of internal quality control and overall quality assurance practices used by the NWQL are provided in reports by Friedman and Erdmann (1982), Jones (1987), and Pritt and Raese (1995). Water samples analyzed by the NWQL were collected in accordance with a quality assurance plan for quality-of-water activities conducted by personnel at the INEL Project Office. The plan was finalized in June 1989, revised in March 1992, and is available for inspection at the USGS Project Office at the INEL. Water samples analyzed by ISU were collected in accordance with procedures described by B. Graham (ISU, written commun., 1991). About 10 percent of the water samples were quality assurance samples. Sample MV-44 is a replicate of sample MV-38. Sample MV-60 is a replicate of sample MV-55.

\section{RADIONUCLIDES}

Water samples were analyzed for strontium90 , tritium, gross alpha- and gross beta-particle radioactivity. In addition, gamma-emitting radionuclides were identified. The samples were analyzed using methods described by Thatcher and others (1977). Maximum contaminant levels for the types of radioactivity and for selected radionuclides are listed on table 3 .

An analytical uncertainty, $s$, is calculated for each radionuclide concentration. This report presents the analytical uncertainty as $2 \mathrm{~s}$. Guidelines for interpreting analytical results are based on an extension of the method described by Currie (1984). In radiochemical analyses, laboratory measurements are made on a target sample and a prepared blank. Instrument signals for the sample and blank vary randomly. Therefore, it is essential to distinguish between two key aspects of the problem of detection: (1) The instrument signal for the sample must be greater than the signal for the blank to make the decision that there was detection; and (2) an estimation must be made of the minimum concentration that will yield a sufficiently large signal to make the correct decision for detection or nondetection most of the time. The first aspect of the problem is a qualitative decision based on signals and a definite criterion for detection. The second aspect of the problem is an estimation of the detection capabilities of a complete measurement process that includes hypothesis testing.

In the laboratory, instrument signals must exceed a critical level of $1.6 \mathrm{~s}$ to make the qualitative decision whether the radionuclide or radioactivity was detected. At $1.6 \mathrm{~s}$, there is about a 95-percent probability that the correct decisionnot detected-will be made. Given a large number of samples, as many as 5 percent of the samples with measured concentrations greater than or equal to $1.6 \mathrm{~s}$, which were concluded as being detected, might not contain the radioactive constituent. These measurements are referred to as false positives and are errors of the first kind in hypothesis testing. 
Once the critical level of $1.6 \mathrm{~s}$ has been defined, the minimum detectable concentration can be established. Concentrations that equal $3 \mathrm{~s}$ represent a measurement at the minimum detectable concentration. For true concentrations of $3 \mathrm{~s}$ or greater, there is a 95-percent-or-more probability of correctly concluding that the radioactive constituent was detected in a sample. Given a large number of samples, as many as 5 percent of the samples with measured concentrations greater than or equal to $3 \mathbf{s}$, which were concluded as being not detected, could contain the radioactive constituent at the minimum detectable concentration. These measurements are referred to as false negatives and are errors of the second kind in hypothesis testing.

True radionuclide concentrations between 1.6s and $3 \mathrm{~s}$ have larger errors of the second kind. That is, there is a greater-than-5-percent probability of false negative results for samples with true concentrations between $1.6 \mathrm{~s}$ and $3 \mathrm{~s}$, and although the radionuclide or radioactivity might have been detected, such detection may not be considered reliable; at $1.6 \mathrm{~s}$, the probability of a false negative is about 50 percent.

These guidelines are based on counting statistics alone and do not include systematic or random errors inherent in laboratory procedures. The values $1.6 \mathrm{~s}$ and $3 \mathrm{~s}$ vary slightly with background or blank counts and with the number of gross counts for individual analyses. The use of the critical level and minimum detectable concentration aids the reader in the interpretation of analytical results and does not represent absolute concentrations of radioactivity that may or may not have been detected. In this report, if the concentration of a selected radionuclide was equal to or greater than $3 \mathrm{~s}$, the concentration is considered to be above a "reporting level." The reporting level should not be confused with the analytical method detection limit, which is based on laboratory procedures. At small concentrations, the reporting level approaches the analytical method detection limit; however, at larger concentrations, they may be significantly different.

Many analytical results of environmental radioactivity measurements are at or near zero. If the true concentration for a given radionuclide is zero, a given set of analytical results for that radionuclide should be distributed about zero, with an equal number of negative and positive measurements. Negative analytical results occur if the radioactivity of a water sample is less than the background radioactivity or the radioactivity of the prepared blank sample in the laboratory (American Society for Testing and Materials, 1992, p. 126; Knobel and others, 1992, p. 50).

\section{Strontium-90}

Strontium-90 is a fission product that was widely distributed in the environment during atmospheric weapons tests. Strontium-90 generally is present in ground water as a result of these tests and from nuclear industry waste-disposal practices. All water samples analyzed contained concentrations of dissolved strontium-90 less than the reporting level (table 4).

\section{Tritium}

Tritium, a radioactive isotope of hydrogen, is formed in nature by interactions of cosmic rays with gases in the upper atmosphere. Tritium also is produced in thermonuclear detonations and is a waste product of the nuclear power industry. Samples were submitted to the ISU laboratory and the NWQL. The ISU laboratory used a liquid scintillation technique and the NWQL used an enrichment and gas counting technique. The analytical method detection limit for the laboratories differed. The analytical method detection limit for the ISU laboratory was $300 \mathrm{pCi} / \mathrm{L}$ using a 200 -minute counting period, and that for the NWQL was $0.3 \mathrm{pCi} / \mathrm{L}$ using a 360 - to 1,200 -minute counting period.

The concentrations of tritium in the water samples are shown on table 4. Concentrations of tritium in 17 of the water samples analyzed by the NWQL were greater than the reporting level and ranged from $1.34 \pm 0.576$ to $59.5 \pm 3.84 \mathrm{pCi} / \mathrm{L}$ (table 4). Concentrations of tritium in all water samples analyzed by the ISU laboratory were less than the reporting level. For the purpose of comparison, background concentrations of tritium in ground water in Idaho generally range from 0 to $40 \mathrm{pCi} / \mathrm{L}$ (Knobel and others, 1992). The maximum 
Table 4. Concentrations of strontium-90 and tritium in water from selected wells and springs, eastern Snake River Plain

[See figure 2 for location of sites. Analyses were performed by the U.S. Geological Survey National Water Quality Laboratory (NWQL) and Idaho State University (ISU) Environmental Monitoring Laboratory using the following methods: strontium-90 by chemical separation and precipitation; tritium by enrichment and gas counting at the NWQL and by liquid scintillation at ISU. Analytical results and uncertainties-for example 1.34 \pm 0.576 -in picocuries per liter. Analytical uncertainties are reported as 28. Concentrations that exceed the reporting level of 3 times 18 are shown in bold-face type. Symbol: *, quality assurance sample (MV-44 is a replicate of MV-38; MV-60 is a replicate of MV-55)]

\begin{tabular}{|c|c|c|c|}
\hline Site Identifier & Strontium-90, NWQL & Tritlum, NWQL & Tritium, ISU \\
\hline MV_03 & $0.107 \pm 0.255$ & $1.34 \pm 0.576$ & $110 \pm 120$ \\
\hline MV-05 & $.085 \pm 0.252$ & $12.4 \pm 1.02$ & $120 \pm 120$ \\
\hline MV-06 & $.147 \pm 0.298$ & $57.3 \pm 3.84$ & $70 \pm 120$ \\
\hline MV-07 & $-.038 \pm 0.179$ & $.00 \pm 0.640$ & $120 \pm 120$ \\
\hline MV-13 & $.124 \pm 0.198$ & $55.7 \pm 3.84$ & $20 \pm 90$ \\
\hline MV-17 & $.116 \pm 0.243$ & $7.87 \pm 0.640$ & $80 \pm 120$ \\
\hline MV-26 & $-.004 \pm 0.245$ & $7.97 \pm 0.768$ & $120 \pm 120$ \\
\hline MV-27 & $.157 \pm 0.205$ & $37.8 \pm 2.56$ & $0 \pm 90$ \\
\hline MV-31 & $.388 \pm 0.295$ & $33.6 \pm 1.92$ & $60 \pm 120$ \\
\hline MV-36 & $.129 \pm 0.267$ & $53.4 \pm 3.84$ & $140 \pm 120$ \\
\hline MV-38 & $.212+0.271$ & $40.0 \pm 2.56$ & $40 \pm 120$ \\
\hline MV-42 & $.043 \pm 0.250$ & $22.1 \pm 1.47$ & $110 \pm 120$ \\
\hline MV-44* & $.311 \pm 0.303$ & $37.4 \pm 2.56$ & $150 \pm 120$ \\
\hline MV-45 & $.096 \pm 0.236$ & $16.5 \pm 1.09$ & $40 \pm 120$ \\
\hline MV-53 & $.184 \pm 0.215$ & $59.5 \pm 3.84$ & $50 \pm 90$ \\
\hline MV-55 & $.134 \pm 0.261$ & $7.65 \pm 0.768$ & $80 \pm 120$ \\
\hline MV-57 & $.041+0.224$ & $.544 \pm 0.640$ & $50 \pm 120$ \\
\hline MV-58 & $.142+0.209$ & $40.0 \pm 2.56$ & $150 \pm 120$ \\
\hline MV-60* & $.238 \pm 0.255$ & $8.06 \pm 0.832$ & $90 \pm 120$ \\
\hline
\end{tabular}

contaminant level for tritium in public drinkingwater supplies is $20,000 \mathrm{pCi} / \mathrm{L}$ (table 3 ).

\section{Gross Alpha-Particle Radioactivity}

Gross alpha-particle radioactivity is a measure of the total radioactivity given off as alpha particles during the radioactive decay process; however, laboratories normally report the radioactivity as if it were all given off by one radionuclide. In this report, concentrations are reported both as natural uranium in micrograms per liter and as thorium-230 in picocuries per liter by the NWQL, and as americium-241 in picocuries per liter by the ISU laboratory.
Concentrations of dissolved gross alphaparticle radioactivity reported as uranium and thorium-230 in two of the water samples analyzed by the NWQL were greater than the reporting level (table 5); MV-31 had concentrations of $17.4 \pm 7.66 \mu \mathrm{g} / \mathrm{L}$ and $10.9 \pm 4.65 \mathrm{pCi} / \mathrm{L}$, and $\mathrm{MV}-57$ had concentrations of $2.68 \pm 1.45 \mu \mathrm{g} / \mathrm{L}$ and $1.71 \pm 0.931 \mathrm{pCi} / \mathrm{L}$, respectively. Total concentrations of gross alpha-particle radioactivity reported as americium-241 in all the water samples analyzed by ISU were less than the reporting level.

\section{Gross Beta-Particle Radioactivity}

Gross beta-particle radioactivity is a measure of the total radioactivity given off as beta particles 
Table 5. Concentrations of gross alpha-particle radioactivity in water from selected wells and springs, eastern Snake River Plain

[See figure 2 for location of sites. Analyses were performed by the U.S. Geological Survey National Water Quality Laboratory (NWQL) and the Idaho State University (ISU) Environmental Monitoring Laboratory using a residue procedure. Analytical results and uncertainties-for example 5.75 \pm 4.82 -in indicated units. Analytical uncertainties are reported as $2 \mathrm{~s}$. Concentrations that exceed the reporting level of 3 times $1 \mathrm{~s}$ are shown in bold-face type. Abbreviations: $\mu \mathrm{g} / \mathrm{L}$, microgram per liter, pCi/L, picocurie per liter. Symbol: *, quality assurance sample (MV-44 is a replicate of MV- 38 ; MV-60 is a replicate of MV-55)]

\begin{tabular}{cccc}
\hline Site identifier & $\begin{array}{c}\text { Dissolved as uranium, } \\
\text { NWQL }\left(\mu g^{\prime} \text { L) }\right.\end{array}$ & $\begin{array}{c}\text { Dissolved as thorium-230, } \\
\text { NWQL (pClL) }\end{array}$ & $\begin{array}{c}\text { Total as americium-241, } \\
\text { ISU (pCLL) }\end{array}$ \\
\hline MV-03 & $0.462 \pm 2.55$ & $0.218 \pm 1.20$ & $0 \pm 5$ \\
MV-05 & $5.75 \pm 4.82$ & $3.56 \pm 2.96$ & $-1 \pm 6$ \\
MV-06 & $6.71 \pm 5.00$ & $4.22 \pm 3.11$ & $1 \pm 7$ \\
MV-07 & $4.31 \pm 3.50$ & $3.36 \pm 2.71$ & $-4 \pm 5$ \\
MV-13 & $6.62 \pm 4.93$ & $4.20 \pm 3.09$ & $-2 \pm 6$ \\
MV-17 & $.137 \pm 2.42$ & $.103 \pm 1.82$ & $-2 \pm 5$ \\
MV-26 & $3.07 \pm 3.27$ & $2.22 \pm 2.36$ & $-1 \pm 5$ \\
MV-27 & $4.29 \pm 4.61$ & $2.56 \pm 2.73$ & $-1 \pm 6$ \\
MV-31 & $17.4 \pm 7.66$ & $10.9 \pm 4.65$ & $1 \pm 7$ \\
MV-36 & $6.26 \pm 4.29$ & $4.54 \pm 3.08$ & $1 \pm 6$ \\
MV-38 & $2.12 \pm 2.95$ & $1.62 \pm 2.26$ & $2 \pm 5$ \\
MV-42 & $4.33 \pm 3.69$ & $3.21 \pm 2.72$ & $-1 \pm 5$ \\
MV-44* & $1.32 \pm 2.72$ & $1.01 \pm 2.08$ & $0 \pm 5$ \\
MV-45 & $5.06 \pm 3.68$ & $3.96 \pm 2.85$ & $1 \pm 5$ \\
MV-53 & $2.81 \pm 4.61$ & $1.55 \pm 2.54$ & $-1 \pm 7$ \\
MV-55 & $-1.05 \pm 1.87$ & $-.808 \pm 1.44$ & $-2 \pm 5$ \\
MV-57 & $2.68 \pm 1.45$ & $1.71 \pm 0.931$ & $0 \pm 5$ \\
MV-58 & $.0928 \pm 1.64$ & $.0585 \pm 1.03$ & $-4 \pm 4$ \\
MV-60* & $4.28 \pm 3.65$ & $3.20 \pm 2.71$ & $-3 \pm 5$ \\
\hline
\end{tabular}

during the radioactive decay process. The laboratory instruments for these measurements are calibrated to either a single radionuclide, cesium-137, or a pair of radionuclides, strontium-90 in equilibrium with yttrium-90. In this report, concentrations are reported as cesium-137 in picocuries per liter and as strontium-90 in equilibrium with yttrium-90 in picocuries per liter. Reporting of the concentrations of gross beta-particle radioactivity in either one of these ways is for reference purposes only and does not imply that the radioactivity is attributed to these specific isotopes. The average annual concentrations of strontium-90 and cesium-137 in public drinking-water supplies that produce a 4-mrem/yr dose are $8 \mathrm{pCi} / \mathrm{L}$ and
$120 \mathrm{pCi} / \mathrm{L}$, respectively. Gross beta-particle radioactivity measurements should not be compared directly with these concentrations.

Concentrations of dissolved gross beta-particle radioactivity reported as cesium-137 and as strontium-90 in equilibrium with yttrium-90 in 16 of the water samples analyzed by the NWQL were greater than the reporting levels (table 6) and ranged from $3.48 \pm 1.06$ to $13.1 \pm 4.37 \mathrm{pCi} / \mathrm{L}$, and $2.66 \pm 1.62$ to $8.18 \pm 3.40 \mathrm{pCi} / \mathrm{L}$, respectively. Concentrations of total gross beta-particle radioactivity reported as cesium-137 in 17 of the water samples analyzed by ISU were equal to or greater than the reporting level (table 6) and ranged from $3 \pm 2$ to $9 \pm 2 \mathrm{pCi} / \mathrm{L}$. 
Table 6. Concentrations of gross beta-particle radioactivity in water from selected wells and springs, eastern Snake River Plain

[See figure 2 for location of sites. Analyses were performed by the U.S. Geological Suney National Water Quality Laboratory (NWQL) and Idaho State University (ISU) Environmental Monitoring Laboratory using a residue procedure. Analytical results and uncertainties-for example $4.58 \pm 2.91$ in picocuries per liter. Analytical uncertainties are reported as $2 \mathrm{~s}$. Concentrations that equal or exceed the reporting level of 3 times 1 are shown in bold-face type. Abbreviation: Sr-90/Y-90, strontium-90 in equilibrium with yttrium-90. Symbol: *, quality assurance sample (MV-44 is a replicate of MV-38; MV-60 is a replicate of MV-55)]

\begin{tabular}{|c|c|c|c|}
\hline Site identifier & $\begin{array}{c}\text { Dissolved as cesium-137, } \\
\text { NWQL }\end{array}$ & $\begin{array}{c}\text { Dissolved as Sr-90/Y-90, } \\
\text { NWQL }\end{array}$ & $\begin{array}{c}\text { Total as cesium-137, } \\
\text { ISU }\end{array}$ \\
\hline MV-03 & $4.58 \pm 2.91$ & $2.66 \pm 1.62$ & $3 \pm 2$ \\
\hline MV-05 & $12.0 \pm 5.38$ & $8.18 \pm 3.40$ & $6 \pm 2$ \\
\hline MV-06 & $7.93 \pm 4.86$ & $5.44 \pm 3.20$ & $0 \pm 2$ \\
\hline MV-07 & $6.49 \pm 4.24$ & $5.03 \pm 3.19$ & $6 \pm 2$ \\
\hline MV-13 & $10.1+5.09$ & $6.95 \pm 3.31$ & $9 \pm 2$ \\
\hline MV-17 & $7.01 \pm 4.14$ & $5.32 \pm 3.03$ & $5 \pm 2$ \\
\hline MV-26 & $9.02 \pm 4.63$ & $6.70+3.27$ & $4 \pm 2$ \\
\hline MV-27 & $9.57 \pm 5.18$ & $6.37 \pm 3.28$ & $7 \pm 2$ \\
\hline MV-31 & $13.1 \pm 4.37$ & $6.87 \pm 1.87$ & $5 \pm 2$ \\
\hline MV-36 & $7.03 \pm 4.22$ & $5.23 \pm \mathbf{3 . 0 3}$ & $2 \pm 2$ \\
\hline MV-38 & $4.71+3.85$ & $3.61 \pm 2.90$ & $3 \pm 2$ \\
\hline$M V-42$ & $8.65 \pm 4.36$ & $6.52 \pm 3.12$ & $6 \pm 2$ \\
\hline MV-44* & $7.57 \pm 4.16$ & $5.81 \pm 3.06$ & $4 \pm 2$ \\
\hline MV-45 & $6.10 \pm 4.19$ & $4.73 \pm 3.16$ & $5 \pm 2$ \\
\hline MV-53 & $9.57 \pm 5.40$ & $6.09 \pm 3.27$ & $7 \pm 2$ \\
\hline MV-55 & $8.46 \pm 4.25$ & $6.51 \pm 3.11$ & $4 \pm 2$ \\
\hline MV-57 & $3.48 \pm 1.06$ & $2.99 \pm 0.738$ & $4 \pm 2$ \\
\hline MV-58 & $4.94 \pm 2.44$ & $3.40 \pm 1.58$ & $3 \pm 2$ \\
\hline MV-60* & $4.39 \pm 3.87$ & $3.32+2.88$ & $5 \pm 2$ \\
\hline
\end{tabular}

\section{Cesium-137}

Gamma spectrometry involves using a series of detectors to simultaneously determine the concentrations of a variety of radionuclides by the identification of their characteristic gamma emissions. When no specific gamma-emitting radionuclides are identified, the concentration is reported by ISU as total cesium-137. Cesium-137 is a fission product of uranium-235, uranium-233, or plutonium-239. Concentrations of total cesium137 in all water samples were less than the reporting level (table 7).

\section{STABLE ISOTOPES}

Water samples were analyzed for relative concentrations of stable isotopes of hydrogen $(\mathrm{H})$, oxygen (O), carbon (C), sulfur (S), and nitrogen (N). Because the absolute measurement of isotopic ratios is analytically difficult, relative isotopic ratios are measured instead (Toran, 1982). For example,

${ }^{18} \mathrm{O} /{ }^{16} \mathrm{O}$ of a sample is compared with ${ }^{18} \mathrm{O} /{ }^{16} \mathrm{O}$ of a standard:

$\delta^{18} \mathrm{O}=\left(\mathrm{R}_{\text {sample }} / \mathrm{R}_{\text {standard }}-1\right) \times 1,000$, where

$R_{\text {sample }}={ }^{18} \mathrm{O} /{ }^{16} \mathrm{O}$ in the sample,

$\mathrm{R}_{\text {standard }}={ }^{18} \mathrm{O} /{ }^{16} \mathrm{O}$ in the standard, and

$\delta^{18} \mathrm{O}=$ relative concentration, in units of parts per thousand (permil).

Delta ${ }^{18} \mathrm{O}\left(\delta^{18} \mathrm{O}\right)$ is referred to as delta notation and is the value reported by isotopic laboratories for stable isotope analysis. ${ }^{2} \mathrm{H} /{ }^{1} \mathrm{H}$, 
${ }^{13} \mathrm{C} /{ }^{12} \mathrm{C},{ }^{34} \mathrm{~S} /{ }^{32} \mathrm{~S}$, and ${ }^{15} \mathrm{~N} /{ }^{14} \mathrm{~N}$ are defined in a similar manner with the respective ratios replacing ${ }^{18} \mathrm{O} /{ }^{16} \mathrm{O}$ in $\mathrm{R}_{\text {sample }}$ and $\mathrm{R}_{\text {standard. }}$ The standard used for determining $\delta^{18} \mathrm{O}$ and $\delta^{2} \mathrm{H}$ in water is standard mean ocean water as defined by Craig (1961). The standard used for determining $\delta^{13} \mathrm{C}$ in water is the PeeDee Belemnite reference standard (Timme, 1995, p. 71). The standard used for determining $\delta^{34} \mathrm{~S}$ in water is the Vienna Canyon Diablo Troilite reference standard (Carmody, USGS, written commun., 1996). The standard used for determining $\delta^{15} \mathrm{~N}$ in water is air (Timme, 1995, p. 71). The respective precisions of measurement for $\delta^{2} \mathrm{H}, \delta^{18} \mathrm{O}, \delta^{13} \mathrm{C}, \delta^{34} \mathrm{~S}$, and $\delta^{15} \mathrm{~N}$ are 2 permil, 0.2 permil, 0.3 permil, 0.2 permil, and 0.2 permil at the 95 -percent confidence level (Timme, 1995, p. 71-72; Carmody, USGS, written commun., 1996).

Table 7. Concentrations of cesium-137 in water from selected wells and springs, eastern Snake River Plain

[See figure 2 for location of sites. Analyses were performed by the Idaho State University Environmental Monitoring Laboratory using gamma spectrometry. Analytical results and uncertainties-for example - $0.64 \pm 3.42$-are for total concentrations in picocuries per liter. Analytical uncertainties are reported as $2 \mathbf{s}$. Symbol: *, quality assurance sample (MV-44 is a replicate of MV-38; MV-60 is a replicate of MV-55)]

\begin{tabular}{lr}
\hline Site identifier & Cesium-137 \\
\hline MV-03 & $-0.64 \pm 3.42$ \\
MV-05 & $.50 \pm 1.98$ \\
MV-06 & $.71 \pm 1.84$ \\
MV-07 & $.81 \pm 3.66$ \\
MV-13 & $.63 \pm 5.60$ \\
MV-17 & $.44 \pm 2.05$ \\
MV-26 & $1.93 \pm 4.70$ \\
MV-27 & $1.88 \pm 3.66$ \\
MV-31 & $-2.50 \pm 3.88$ \\
MV-36 & $.58 \pm 4.32$ \\
MV-38 & $2.45 \pm 3.94$ \\
MV-42 & $-2.97 \pm 4.14$ \\
MV-44* & $2.43 \pm 2.18$ \\
MV-45 & $.29 \pm 5.34$ \\
MV-53 & $2.47 \pm 3.62$ \\
MV-55 & $2.36 \pm 3.74$ \\
MV-57 & $1.99 \pm 4.16$ \\
MV-58 & $.69 \pm 4.32$ \\
MV-60* & $-.44 \pm 2.00$ \\
\hline
\end{tabular}

Relative concentrations of stable isotopes are shown in table 8 . Relative isotopic ratios reported as $\delta^{2} \mathrm{H}$ for water from 19 samples ranged from -139 to -128 permil. Relative isotopic ratios reported as $\delta^{18} \mathrm{O}$ for water from 19 samples ranged from -18.10 to -16.29 permil. Relative isotopic ratios reported as $\delta^{13} \mathrm{C}$ for water from 19 samples ranged from -13.0 to -8.1 permil. Relative isotopic ratios reported as $\delta^{34} \mathrm{~S}$ for water from 19 samples ranged from 5.5 to 16.2 permil. Relative isotopic ratios reported as $\delta^{15} \mathrm{~N}$ for water from 18 samples ranged from 2.8 to 6.2 permil.

\section{INORGANIC CONSTITUENTS}

Water samples were analyzed for selected inorganic constituents. These constituents included trace elements, common ions, and nutrients. In this report, minimum reporting levels and method detection limits established for these constituents are not to be confused with reporting levels and analytical method detection limits for selected radionuclides. The minimum reporting level for inorganic and organic constituents is the smallest measured concentration of a constituent that may be reliably reported using a given analytical method (Timme, 1995, p. 92). The method detection limit is defined as the minimum concentration of a substance that can be identified, measured, and reported with 99-percent confidence that the analyte concentration is greater than zero and is determined from analysis of a sample in a given matrix containing the analyte (Timme, 1995, p. 92).

\section{Trace Elements}

Water samples were analyzed for selected dissolved trace elements including aluminum, arsenic, barium, beryllium, cadmium, chromium, cobalt, copper, iron, lead, lithium, manganese, mercury, molybdenum, nickel, selenium, silver, strontium, vanadium, and zinc. Water samples also were analyzed for hexavalent and total chromium. The maximum or secondary maximum contaminant levels and minimum reporting levels of selected trace elements are shown on table 9. The concentrations of dissolved trace elements and hexavalent and total chromium are shown on table 10. 
Table 8. Relative concentrations of stable isotopes in water from selected wells and springs, eastern Snake River Plain

[See figure 2 for location of sites. Analyses were performed by the U.S. Geological Survey National Water Quality Laboratory. Symbols: $\delta^{2} \mathrm{H}$, delta notation for stable hydrogen isotope ratios; $\delta^{18} \mathrm{O}$, delta notation for stable oxygen isotope ratios; $\delta^{13} \mathrm{C}$, delta notation for stable carbon isotope ratios; $\delta^{34} \mathrm{~S}$, delta notation for stable sulfur isotope ratios; $\delta^{15} \mathrm{~N}$, delta notation for stable nitrogen isotope ratios; \pm , plus or minus; permil, parts per thousand relative to a standard; ${ }^{*}$, quality assurance sample (MV-44 is a replicate of MV-38; MV-60 is a replicate of MV-55); BL, bottle broke in laboratory]

\begin{tabular}{lccccc}
\hline Site identifier & $\begin{array}{c}\delta^{2} \mathbf{H} \\
( \pm 2 \text { permil) }\end{array}$ & $\begin{array}{c}\delta^{18} \mathbf{O} \\
( \pm 0.2 \text { permil })\end{array}$ & $\begin{array}{c}\delta^{13} \mathbf{C} \\
( \pm 0.3 \text { permil })\end{array}$ & $\begin{array}{c}\delta^{34} \mathbf{S} \\
( \pm 0.2 \text { permil })\end{array}$ & $\begin{array}{c}\delta^{15} \mathbf{N} \\
( \pm 0.2 \text { permil) }\end{array}$ \\
\hline MV-03 & -136 & -18 & -10.1 & 12.7 & 3.7 \\
MV-05 & -134 & -17.73 & -10.7 & 12.1 & 4.2 \\
MV-06 & -128 & -16.29 & -12.1 & 14.7 & 3.8 \\
MV-07 & -138 & -18.10 & -9.1 & 16.2 & 4.2 \\
MV-13 & -128 & -16.51 & -10.8 & 12.0 & 6.2 \\
MV-17 & -136 & -17.8 & -9.7 & 14.1 & 4.4 \\
MV-26 & -136 & -17.79 & -9.9 & 13.4 & 4.3 \\
MV-27 & -134 & -17.16 & -11.1 & 11.6 & 5.1 \\
MV-31 & -133 & -17.27 & -11.1 & 12.2 & 5.4 \\
MV-36 & -130 & -17.12 & -13.0 & 9.6 & 5.9 \\
MV-38 & -134 & -17.27 & -12.1 & 10.7 & 4.1 \\
MV-42 & -134 & -17.44 & -11.4 & 13.3 & 6.1 \\
MV-44* & -133 & -17.34 & -12.2 & 10.8 & 5.0 \\
MV-45 & -135 & -17.65 & -9.8 & 11.7 & 4.7 \\
MV-53 & -131 & -16.8 & -11.7 & 11.8 & $\mathbf{B L}$ \\
MV-55 & -138 & -17.85 & -10.5 & 13.8 & 5.4 \\
MV-57 & -139 & -18.02 & -8.1 & 5.5 & 2.8 \\
MV-58 & -135 & -17.59 & -11.3 & 6.9 & 4.2 \\
MV-60* & -136 & -17.85 & -10.3 & 13.8 & 5.1 \\
\hline
\end{tabular}


Table 9. Maximum contaminant levels and minimum reporting levels of selected trace elements in drinking water [The maximum contaminant levels are for total measurements and were established pursuant to the recommendations of the U.S. Environmental Protection Agency $(1994 ; 1995$, p. 912, 974) for community water systems and are for comparison purposes only. Secondary maximum contaminant levels-in brackets-are from U.S. Environmental Protection Agency $(1995$, p. 1,055). Minimum reporting levels are from Timme (1995). Units are in micrograms per liter $(\mu g / L)$. Symbols: $\cdots$, maximum contaminant level has not been established; ${ }^{*}$, lead has an action level of $\left.15 \mu \mathrm{g} / \mathrm{L}\right]$

\begin{tabular}{|c|c|c|}
\hline Constituent & Maximum contaminant level & Minimum reporting level \\
\hline Aluminum & [50 to 200$]$ & 10 \\
\hline Arsenic & 50 & 1 \\
\hline Barium & 2,000 & 1 \\
\hline Beryllium & 4 & .5 \\
\hline Cadmium & 5 & 1 \\
\hline Chromium, dissolved & $\bullet$ & 5 \\
\hline Chromium, hexavalent & $\bullet$ & 1 \\
\hline Chromium, total & 100 & 1 \\
\hline Cobalt & $\bullet$ & 3 \\
\hline Copper & {$[1,000]$} & 10 \\
\hline Iron & [300] & 3 \\
\hline Lead & $*$ & 1 \\
\hline Lithium & $\cdots$ & 4 \\
\hline Manganese & {$[50]$} & 1 \\
\hline Mercury & 2 & .1 \\
\hline Molybdenum & $\bullet$ & 10 \\
\hline Nickel & 100 & 10 \\
\hline Selenium & 50 & 1 \\
\hline Silver & {$[100]$} & 1 \\
\hline Strontium & $\bullet$ & .5 \\
\hline Vanadium & $\bullet$ & 6 \\
\hline Zinc & {$[5,000]$} & 3 \\
\hline
\end{tabular}


Table 10. Concentrations of dissolved trace elements and hexavalent and total chromium in water from selected wells and springs, eastern Snake River Plain [See figure 2 for location of sites. Analyses were performed by the U.S. Geological Survey National Water Quality Laboratory. Analytical results in micrograms per liter. Symbols: <, concentration was less than the respective minimum reporting level; ${ }^{*}$, quality assurance sample (MV-44 is a replicate of MV-38; MV-60 is a replicate of MV-55)]

\begin{tabular}{|c|c|c|c|c|c|c|c|c|c|c|c|}
\hline \multirow{2}{*}{$\begin{array}{c}\text { Site } \\
\text { identifier }\end{array}$} & \multirow[b]{2}{*}{ Aluminum } & \multirow[b]{2}{*}{ Arsenic } & \multirow[b]{2}{*}{ Barium } & \multirow[b]{2}{*}{ Beryllium } & \multirow[b]{2}{*}{ Cadmium } & \multicolumn{3}{|c|}{ Chromium } & \multirow[b]{2}{*}{ Cobalt } & \multirow[b]{2}{*}{ Copper } & \multirow[b]{2}{*}{ Iron } \\
\hline & & & & & & dissolved & hexavalent & total & & & \\
\hline MV-03 & 30 & 2 & 23 & $<0.5$ & 2 & $<5$ & $<1$ & 2.1 & $<3$ & $<10$ & $<3$ \\
\hline MV-05 & 20 & 3 & 53 & $<.5$ & $<1$ & $<5$ & $<1$ & 2 & $<3$ & $<10$ & $<3$ \\
\hline MV-06 & $<10$ & 3 & 78 & $<.5$ & $<1$ & $<5$ & 1 & 1 & 5 & $<10$ & $<3$ \\
\hline MV-07 & $<10$ & 2 & 21 & $<.5$ & 3 & $<5$ & $<1$ & 3 & $<3$ & $<10$ & 13 \\
\hline MV-13 & 30 & 4 & 78 & $<.5$ & 4 & $<5$ & $<1$ & 1 & $<3$ & $<10$ & $<3$ \\
\hline MV-17 & $<10$ & 2 & 25 & $<.5$ & $<1$ & $<5$ & $<1$ & 7.6 & $<3$ & $<10$ & $<3$ \\
\hline MV-26 & $<10$ & 2 & 27 & $<.5$ & $<1$ & $<5$ & $<1$ & 2.3 & $<3$ & $<10$ & $<3$ \\
\hline MV-27 & $<10$ & 2 & 58 & $<.5$ & $<1$ & $<5$ & $<1$ & 1.8 & $<3$ & $<10$ & $<3$ \\
\hline MV-31 & $<10$ & 2 & 52 & $<.5$ & $<1$ & $<5$ & $<1$ & 2.2 & $<3$ & $<10$ & $<3$ \\
\hline MV-36 & 10 & 2 & 40 & $<.5$ & $<1$ & $<5$ & $<1$ & 1.6 & $<3$ & $<10$ & $<3$ \\
\hline MV-38 & $<10$ & 1 & 29 & $<.5$ & $<1$ & $<5$ & $<1$ & 2.4 & $<3$ & $<10$ & $<3$ \\
\hline$M V-42$ & 50 & 3 & 24 & $<.5$ & $<1$ & $<5$ & $<1$ & 9 & $<3$ & $<10$ & $<3$ \\
\hline $\mathrm{MV}-44^{*}$ & $<10$ & 1 & 29 & $<.5$ & $<1$ & $<5$ & $<1$ & 2.4 & $<3$ & $<10$ & 5 \\
\hline MV-45 & $<10$ & 2 & 21 & .7 & 4 & $<5$ & 3 & 3.6 & $<3$ & $<10$ & 21 \\
\hline MV-53 & $<10$ & 2 & 91 & $<.5$ & 1 & $<5$ & $<1$ & 1.3 & $<3$ & $<10$ & 5 \\
\hline MV-55 & 20 & 2 & 23 & $<.5$ & $<1$ & $<5$ & 1 & 2.9 & $<3$ & $<10$ & 3 \\
\hline MV-57 & $<10$ & 2 & 5 & $<.5$ & $<1$ & $<5$ & 3 & 3 & $<3$ & $<10$ & $<3$ \\
\hline MV-58 & 20 & 2 & 18 & $<.5$ & $<1$ & $<5$ & $<1$ & 2.4 & $<3$ & $<10$ & 4 \\
\hline MV-60* & 20 & 2 & 23 & $<.5$ & $<1$ & $<5$ & 1 & 3 & $<3$ & $<10$ & $<3$ \\
\hline
\end{tabular}


Table 10. Concentrations of dissolved trace elements and hexavalent and total chromium in water from selected wells and springs, eastern Snake River Plain-Continued

\begin{tabular}{|c|c|c|c|c|c|c|c|c|c|c|c|}
\hline $\begin{array}{c}\text { Site } \\
\text { identifier }\end{array}$ & Lead & Lithium & Manganese & Mercury & Molybdenum & Nickel & Selenium & Silver & Strontium & Vanadium & Zinc \\
\hline$M V-03$ & $<1$ & 34 & $<1$ & $<0.1$ & 10 & $<10$ & $<1$ & $<1$ & 200 & 7 & $<3$ \\
\hline MV-05 & $<1$ & 39 & $<1$ & $<.1$ & 10 & $<10$ & $<1$ & $<1$ & 340 & 8 & 5 \\
\hline MV-06 & $<1$ & 36 & $<1$ & $<.1$ & $<10$ & $<10$ & $<1$ & 2 & 370 & $<6$ & 4 \\
\hline MV-07 & $<1$ & 25 & $<1$ & $<.1$ & 10 & $<10$ & $<1$ & $<1$ & 190 & $<6$ & 12 \\
\hline MV-13 & $<1$ & 21 & $<1$ & $<.1$ & 20 & $<10$ & $<1$ & $<1$ & 250 & 12 & $<3$ \\
\hline MV-17 & $<1$ & 26 & $<1$ & $<.1$ & $<10$ & $<10$ & $<1$ & $<1$ & 200 & 8 & 8 \\
\hline MV-26 & $<1$ & 32 & $<1$ & $<.1$ & $<10$ & $<10$ & $<1$ & $<1$ & 230 & $<6$ & 10 \\
\hline MV-27 & $<1$ & 44 & $<1$ & $<.1$ & $<10$ & $<10$ & $<1$ & $<1$ & 350 & $<6$ & 5 \\
\hline MV-31 & $<1$ & 36 & $<1$ & $<.1$ & $<10$ & $<10$ & $<1$ & $<1$ & 310 & $<6$ & $<3$ \\
\hline MV-36 & $<1$ & 5 & $<1$ & $<.1$ & $<10$ & $<10$ & $<1$ & 1 & 190 & $<6$ & 4 \\
\hline MV-38 & $<1$ & 6 & $<1$ & $<.1$ & $<10$ & $<10$ & $<1$ & $<1$ & 160 & $<6$ & 6 \\
\hline $\mathrm{MV}-42$ & $<1$ & 18 & $<1$ & $<.1$ & $<10$ & $<10$ & $<1$ & $<1$ & 200 & 12 & 13 \\
\hline MV-44* & $<1$ & 8 & $<1$ & $<.1$ & $<10$ & $<10$ & $<1$ & 2 & 160 & $<6$ & 5 \\
\hline MV-45 & $<1$ & 10 & $<1$ & $<.1$ & 20 & $<10$ & $<1$ & $<1$ & 180 & $<6$ & $<3$ \\
\hline MV-53 & $<1$ & 47 & 2 & $<.1$ & 20 & $<10$ & 1 & $<1$ & 400 & 6 & 86 \\
\hline MV-55 & $<1$ & 26 & $<1$ & $<.1$ & $<10$ & $<10$ & $<1$ & $<1$ & 190 & 8 & 7 \\
\hline MV-57 & $<1$ & 11 & 5 & $<.1$ & $<10$ & $<10$ & $<1$ & $<1$ & 130 & 11 & 22 \\
\hline MV-58 & $<1$ & 7 & 1 & $<.1$ & $<10$ & $<10$ & $<1$ & 1 & 100 & 14 & 60 \\
\hline MV-60* & $<1$ & 23 & $<1$ & $<.1$ & $<10$ & $<10$ & $<1$ & 1 & 190 & 7 & $<3$ \\
\hline
\end{tabular}


Aluminum.-Concentrations of aluminum in eight samples were equal to or greater than the minimum reporting level and ranged from 10 to $50 \mu \mathrm{g} / \mathrm{L}$. The secondary maximum contaminant level is 50 to $200 \mu \mathrm{g} / \mathrm{L}$.

Arsenic.-Concentrations of arsenic in all samples were equal to or greater than the minimum reporting level and ranged from 1 to $4 \mu \mathrm{g} / \mathrm{L}$. The maximum contaminant level is $50 \mu \mathrm{g} / \mathrm{L}$.

Barium.-Concentration of barium in all samples were greater than the minimum reporting level and ranged from 5 to $91 \mu \mathrm{g} / \mathrm{L}$. The maximum contaminant level is $2,000 \mu \mathrm{g} / \mathrm{L}$.

Beryllium.- The concentration of beryllium in one sample (MV-45) was $0.7 \mu \mathrm{g} / \mathrm{L}$; the other samples had concentrations less than the minimum reporting level. The maximum contaminant level is $4 \mu \mathrm{g} / \mathrm{L}$.

Cadmium.-Concentrations of cadmium in five samples were equal to or greater than the minimum reporting level and ranged from 1 to $4 \mu \mathrm{g} / \mathrm{L}$. The maximum contaminant level is $5 \mu \mathrm{g} / \mathrm{L}$.

Chromium.-Chromium analyses included dissolved, hexavalent, and total chromium. All the samples had concentrations of dissolved chromium less than the minimum reporting level of $5 \mu \mathrm{g} / \mathrm{L}$. Concentrations of hexavalent chromium in five samples were equal to or greater than the minimum reporting level and ranged from 1 to $3 \mu \mathrm{g} / \mathrm{L}$. Concentrations of total chromium in all samples were equal to or greater than the minimum reporting level and ranged from 1 to $9 \mu \mathrm{g} / \mathrm{L}$; the maximum contaminant level is $100 \mu \mathrm{g} / \mathrm{L}$.

Cobalt.-The concentration of cobalt in one sample (MV-06) was $5 \mu \mathrm{g} / \mathrm{L}$; the other samples had concentrations less than the minimum reporting level of $3 \mu \mathrm{g} / \mathrm{L}$.

Copper--Concentrations of copper in all samples were less than the minimum reporting level of $10 \mu \mathrm{g} / \mathrm{L}$. The secondary maximum contaminant level is $1,000 \mu \mathrm{g} / \mathrm{L}$.

Iron--Concentrations of iron in six samples were equal to or greater than the minimum report- ing level and ranged from 3 to $21 \mu \mathrm{g} / \mathrm{L}$. The secondary maximum contaminant level is $300 \mu \mathrm{g} / \mathrm{L}$.

Lead.-Concentrations of lead in all samples were less than the minimum reporting level of $1 \mu \mathrm{g} / \mathrm{L}$. Lead has an action level of $15 \mu \mathrm{g} / \mathrm{L}$.

Lithium.-Concentrations of lithium in all samples were greater than the minimum reporting level and ranged from 5 to $47 \mu \mathrm{g} / \mathrm{L}$.

Manganese.-Concentrations of manganese in three samples were equal to or greater than the minimum reporting level and ranged from 1 to 5 $\mu \mathrm{g} / \mathrm{L}$. The secondary maximum contaminant level is $50 \mu \mathrm{g} / \mathrm{L}$.

Mercury.-Concentrations of mercury in all the samples were less than the minimum reporting level of $0.1 \mu \mathrm{g} / \mathrm{L}$. The maximum contaminant level is $2 \mu \mathrm{g} / \mathrm{L}$.

Molybdenum.-Concentrations of molybdenum in six samples were equal to or greater than the minimum reporting level and ranged from 10 to $20 \mu \mathrm{g} / \mathrm{L}$.

Nickel.-Concentrations of nickel in all the samples were less than the minimum reporting level of $10 \mu \mathrm{g} / \mathrm{L}$. The maximum contaminant level is $100 \mu \mathrm{g} / \mathrm{L}$.

Selenium.-The concentration of selenium in one sample (MV-53) was equal to the minimum reporting level of $1 \mu \mathrm{g} / \mathrm{L}$. The maximum contaminant level is $50 \mu \mathrm{g} / \mathrm{L}$.

Silver--Concentrations of silver in five samples were equal to or greater than the minimum reporting level and ranged from 1 to $2 \mu \mathrm{g} / \mathrm{L}$. The secondary maximum contaminant level is $100 \mu \mathrm{g} / \mathrm{L}$.

Strontium.-Concentrations of strontium in all samples were greater than the minimum reporting level and ranged from 100 to $400 \mu \mathrm{g} / \mathrm{L}$.

Vanadium.-Concentrations of vanadium in 10 samples were equal to or greater than the minimum reporting level and ranged from 6 to $14 \mu \mathrm{g} / \mathrm{L}$.

Zinc.-Concentrations of zinc in 14 samples were greater than the minimum reporting level 
and ranged from 4 to $86 \mu \mathrm{g} / \mathrm{L}$. The secondary maximum contaminant level is $5,000 \mu \mathrm{g} / \mathrm{L}$.

\section{Common lons}

Water samples were analyzed for dissolved common ions including bromide, calcium, chloride, fluoride, magnesium, potassium, silica, sodium, and sulfate. The maximum or secondary maximum contaminant levels and the minimum reporting levels of these ions are shown on table 11. The concentrations of dissolved common ions are shown on table 12 .

Bromide.-Concentrations of bromide in all samples were greater than the minimum reporting level and ranged from 0.03 to $0.21 \mathrm{mg} / \mathrm{L}$.

Calcium.-Concentrations of calcium in all samples were greater than the minimum reporting level and ranged from 22 to $67 \mathrm{mg} / \mathrm{L}$.

Chloride. - Concentrations of chloride in all samples were greater than the minimum reporting level and ranged from 5.1 to $72 \mathrm{mg} / \mathrm{L}$. The secondary maximum contaminant level is $250 \mathrm{mg} / \mathrm{L}$.

Fluoride.-Concentrations of fluoride in all samples were greater than the minimum reporting level and ranged from 0.2 to $0.6 \mathrm{mg} / \mathrm{L}$. The maximum contaminant level is $4 \mathrm{mg} / \mathrm{L}$.

Magnesium.-Concentrations of magnesium in all samples were greater than the minimum reporting level and ranged from 11 to $25 \mathrm{mg} / \mathrm{L}$.

Potassium.-Concentrations of potassium in all samples were greater than the minimum reporting level and ranged from 2.5 to $6.9 \mathrm{mg} / \mathrm{L}$.

Silica.-Concentrations of silica in all samples were greater than the minimum reporting level and ranged from 27 to $41 \mathrm{mg} / \mathrm{L}$.

Sodium.- Concentrations of sodium in all samples were greater than the minimum reporting level and ranged from 10 to $54 \mathrm{mg} / \mathrm{L}$. IDHW (1989) recommends an optimum concentration of $20 \mathrm{mg} / \mathrm{L}$ of sodium for public drinking-water supplies.

Sulfate.-Concentrations of sulfate in all samples were greater than the minimum reporting level and ranged from 9.7 to $74 \mathrm{mg} / \mathrm{L}$. The secondary maximum contaminant level is $250 \mathrm{mg} / \mathrm{L}$.

\section{Nutrients}

Water samples were analyzed for dissolved ammonia (as nitrogen), nitrite (as nitrogen), nitrite plus nitrate (as nitrogen), and orthophosphate (as phosphorus). The maximum and secondary maximum contaminant levels established by the U.S. Environmental Protection Agency (1995) and the minimum reporting levels are shown on table 13. A maximum contaminant level has not been established or proposed for ammonia or orthophosphate. Concentrations of nutrients are shown on table 14.

Ammonia (as nitrogen).-Concentrations of ammonia (as nitrogen) in six of the samples were greater than the minimum reporting level and ranged from 0.02 to $0.03 \mathrm{mg} / \mathrm{L}$.

Nitrite (as nitrogen).-Concentrations of nitrite (as nitrogen) in all the samples were less than the minimum reporting level of $0.01 \mathrm{mg} / \mathrm{L}$. The maximum contaminant level is $1 \mathrm{mg} / \mathrm{L}$.

Nitrite plus nitrate (as nitrogen).- Concentrations of nitrite plus nitrate (as nitrogen) in all samples were greater than the minimum reporting level and ranged from 0.41 to $4.8 \mathrm{mg} / \mathrm{L}$. The maximum contaminant level is $10 \mathrm{mg} / \mathrm{L}$.

Orthophosphate (as phosphorus).-Concentrations of orthophosphate (as phosphorus) in 15 samples were equal to or greater than the minimum reporting level and ranged from 0.01 to $0.04 \mathrm{mg} / \mathrm{L}$.

\section{ORGANIC COMPOUNDS}

Water samples were analyzed for selected organic compounds. These compounds included DOC, anionic surfactants as MBAS, purgeable organic compounds, insecticides, gross polychlorinated compounds, and herbicides. Minimum reporting levels and method detection limits established for these constituents (Timme, 1995) are not to be confused with reporting levels and analytical method detection limits for selected radionuclides. 
Table 11. Maximum contaminant levels and minimum reporting levels of selected common ions in drinking water [The maximum contaminant levels are for total measurements and were established pursuant to the recommendations of the U.S. Environmental Protection Agency (1995, p. 974) for community water systems and are for comparison purposes only. Secondary maximum contaminant levels--in brackets-are from U.S. Environmental Protection Agency (1995, p. 1,055). Minimum reporting levels are from Timme (1995). Units are in milligrams per liter ( $\mathrm{mg} / \mathrm{L}$ ). Symbol: $\cdots$, maximum contaminant level has not been established]

\begin{tabular}{|c|c|c|}
\hline Constituent & Maximum contaminant level & Minimum reporting level \\
\hline Bromide & 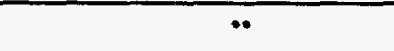 & 0.01 \\
\hline Calcium & 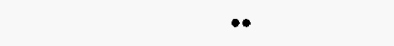 & .02 \\
\hline Chloride & $\begin{array}{r}{[250]} \\
. .\end{array}$ & .1 \\
\hline Fluoride & $\begin{array}{r}4 \\
{[2]}\end{array}$ & .1 \\
\hline Magnesium & $\bullet$ & .01 \\
\hline Potassium & $\bullet$ & .1 \\
\hline Silica & $\bullet$ & .01 \\
\hline Sodium 1 & •• & .2 \\
\hline Sulfate & $\begin{array}{r}{[250]} \\
.\end{array}$ & .1 \\
\hline
\end{tabular}

${ }^{1}$ Idaho Department of Health and Welfare (1989) recommends an optimum concentration of $20 \mathrm{mg} / \mathrm{L}$.

Table 12. Concentrations of dissolved common ions in water from selected wells and springs, eastern Snake River Plain [See figure 2 for location of sites. Analyses were performed by the U.S. Geological Survey National Water Quality Laboratory. Analytical results in milligrams per liter. Symbol: *, quality assurance sample (MV-44 is a replicate of MV-38, MV-60 is a replicate of MV-55)]

\begin{tabular}{|c|c|c|c|c|c|c|c|c|c|}
\hline $\begin{array}{c}\text { Site } \\
\text { identifier }\end{array}$ & Bromide & Calclum & Chloride & Fluoride & Magnesium & Potasslum & Silica & Sodium & Sulfate \\
\hline MV-03 & 0.08 & 41 & 32 & 0.6 & 15 & 3.5 & 33 & 25 & 34 \\
\hline MV-05 & .14 & 52 & 62 & .5 & 22 & 5.1 & 33 & 45 & 71 \\
\hline MV-06 & .06 & 67 & 30 & .2 & 19 & 5.3 & 30 & 23 & 47 \\
\hline MV-07 & .03 & 33 & 13 & .6 & 14 & 3.5 & 31 & 16 & 29 \\
\hline MV-13 & .09 & 48 & 35 & .4 & 18 & 6.3 & 41 & 41 & 55 \\
\hline MV-17 & .05 & 35 & 22 & .5 & 15 & 3.6 & 33 & 20 & 32 \\
\hline MV-26 & .09 & 44 & 32 & .6 & 16 & 3.9 & 33 & 24 & 40 \\
\hline MV-27 & .21 & 62 & 60 & .3 & 24 & 5.2 & 34 & 36 & 66 \\
\hline MV-31 & .14 & 59 & 51 & .4 & 22 & 4.4 & 34 & 32 & 59 \\
\hline MV-36 & .03 & 47 & 7.3 & .3 & 14 & 2.8 & 30 & 14 & 18 \\
\hline MV-38 & .03 & 40 & 8.0 & .3 & 13 & 2.9 & 31 & 15 & 18 \\
\hline $\mathrm{MV}-42$ & .04 & 36 & 16 & .4 & 18 & 3.5 & 35 & 20 & 32 \\
\hline MV-44* & .03 & 38 & 8.0 & .3 & 13 & 3.0 & 31 & 15 & 17 \\
\hline$M V-45$ & .03 & 33 & 11 & .4 & 16 & 3.8 & 33 & 17 & 24 \\
\hline MV-53 & .15 & 62 & 72 & .4 & 25 & 6.9 & 35 & 54 & 74 \\
\hline MV-55 & .05 & 35 & 23 & .6 & 15 & 3.5 & 33 & 19 & 34 \\
\hline MV-57 & .03 & 22 & 6.5 & .4 & 11 & 2.5 & 29 & 10 & 15 \\
\hline MV-58 & .03 & 24 & 5.1 & .4 & 11 & 2.8 & 27 & 14 & 9.7 \\
\hline MV-60* & .05 & 35 & 22 & .5 & 15 & 3.5 & 33 & 19 & 34 \\
\hline
\end{tabular}


Table 13. Maximum contaminant levels and minimum reporting levels of selected nutrients, dissolved organic carbon, and anionic surfactants in drinking water

[The maximum contaminant levels were established pursuant to the recommendations of the U.S. Environmental Protection Agency (1995, p. 974) for community water systems and are included for comparison purposes only. The secondary maximum contaminant level-in brackets - is from U.S. Environmental Protection Agency (1995, p. 1,055). Minimum reporting levels are from Timme (1995). Units are milligrams per liter. Symbol: $\bullet$, maximum contaminant level has not been established or proposed]

\begin{tabular}{lcc}
\hline Constituent & Maximum contaminant level & Minimum reporting level \\
\hline Ammonia (as nitrogen) &. & 0.015 \\
Nitrite (as nitrogen) & 1 & .01 \\
Nitrite plus nitrate (as nitrogen) & 10 & .05 \\
Orthophosphate (as phosphorus) &. & .01 \\
Dissolved organic carbon &.. & .1 \\
Anionic surfactants & {$[0.5]$} & .02 \\
\hline
\end{tabular}

Table 14. Concentrations of nutrients, dissolved organic carbon, and anionic surfactants in water from selected wells and springs, eastern Snake River Plain

[See figure 2 for location of sites. Analyses were performed by the U.S. Geological Survey National Water Quality Laboratory. Analytical results in milligrams per liter. Abbreviation: MBAS, methylene blue active substances. Symbols: <, concentration was less than the respective minimum reporting level; ", quality assurance sample (MV-44 is a replicate of MV-38; MV-60 is a replicate of MV-55)]

\begin{tabular}{ccccccc}
\hline $\begin{array}{c}\text { Site } \\
\text { identifier }\end{array}$ & $\begin{array}{c}\text { Ammonia } \\
\text { (as nitrogen) }\end{array}$ & $\begin{array}{c}\text { Nitrite } \\
\text { (as nitrogen) }\end{array}$ & $\begin{array}{c}\text { Nitrite plus } \\
\text { nitrate } \\
\text { (as nitrogen) }\end{array}$ & $\begin{array}{c}\text { Orthophosphate } \\
\text { (as phosphorus) }\end{array}$ & $\begin{array}{c}\text { Dissolved } \\
\text { organic } \\
\text { carbon }\end{array}$ & $\begin{array}{c}\text { Anionic } \\
\text { surfactants } \\
\text { as MBAS }\end{array}$ \\
\hline MV-03 & $<0.015$ & $<0.01$ & 1.2 & $<0.01$ & 0.5 & $<0.02$ \\
MV-05 & $<.015$ & $<.01$ & 2.2 & .01 & 1.0 & $<.02$ \\
MV-06 & $<.015$ & $<.01$ & 4.3 & .02 & .5 & $<.02$ \\
MV-07 & $<.015$ & $<.01$ & 4.8 & $<.01$ & .3 & $<.02$ \\
MV-13 & $<.015$ & $<.01$ & 1.5 & .01 & .7 & $<.02$ \\
MV-17 & .03 & $<.01$ & .94 & .02 & .4 & $<.02$ \\
MV-26 & $<.015$ & $<.01$ & .91 & $<.01$ & .5 & $<.02$ \\
MV-27 & $<.015$ & $<.01$ & 1.9 & .02 & .8 & $<.02$ \\
MV-31 & .03 & $<.01$ & 1.9 & .01 & .6 & $<.02$ \\
MV-36 & $<.015$ & $<.01$ & 1.3 & .04 & .6 & $<.02$ \\
MV-38 & .03 & $<.01$ & 1.4 & .03 & .3 & $<.02$ \\
MV-42 & $<.015$ & $<.01$ & 1.3 & .03 & .4 & $<.02$ \\
MV-44* & .03 & $<.01$ & 1.3 & .03 & .3 & $<.02$ \\
MV-45 & $<.015$ & $<.01$ & 1.1 & .01 & .5 & $<.02$ \\
MV-53 & $<.015$ & $<.01$ & 3.7 & $<.01$ & .3 & $<.02$ \\
MV-55 & .03 & $<.01$ & .99 & .01 & .3 & $<.02$ \\
MV-57 & $<.015$ & $<.01$ & .41 & .01 & .3 & $<.02$ \\
MV-58 & .02 & $<.01$ & 1.4 & .01 & .3 & $<.2$ \\
MV-60* & $<.015$ & $<.01$ & 1.0 & .01 & .4 & $<.02$ \\
\hline & & & & & .3 & \\
\hline
\end{tabular}




\section{Dissolved Organic Carbon}

Water samples were analyzed for DOC (table 14). Concentrations of DOC in all the samples were greater than the minimum reporting level of $0.1 \mathrm{mg} / \mathrm{L}$ and ranged from 0.2 to $1.3 \mathrm{mg} / \mathrm{L}$; no maximum contaminant level has been established.

\section{Anionic Surfactants}

Water samples were analyzed for anionic surfactants as MBAS (table 14). Concentrations of all but one sample were less than the minimum reporting level of $0.02 \mathrm{mg} / \mathrm{L}$; the secondary maximum contaminant level is $0.5 \mathrm{mg} / \mathrm{L}$. One sample (MV-58) had a concentration less than $0.2 \mathrm{mg} / \mathrm{L}$.

\section{Purgeable Organic Compounds}

Water samples were analyzed for 61 purgeable organic compounds. The maximum contaminant levels and minimum reporting levels of these compounds are shown on table 15 . None of the samples had concentrations of purgeable organic compounds greater than their respective minimum reporting levels (table 15 ).

\section{Insecticides and Gross Polychlorinated Compounds}

Water samples were analyzed for concentrations of 8 carbamate insecticides, 11 organophosphate insecticides, 15 organochlorine insecticides, gross PCB's, and gross PCN's (table 16). The minimum reporting levels ranged from 0.01 to $1.0 \mu \mathrm{g} / \mathrm{L}$. Water samples also were analyzed for an additional group of 19 insecticides that included 11 of the carbamate, organophosphate, and organochlorine insecticides mentioned above. Analyses for the 19 insecticides were made using different laboratory schedules with different minimum reporting levels; therefore, 11 insecticides are listed twice with two different minimum reporting levels. The maximum contaminant levels and minimum reporting levels for all the compounds are shown on table 16 . None of the samples contained concentrations of insecticides or polychlorinated compounds larger than their respective minimum reporting levels.

\section{Herbicides}

Water samples were analyzed for concentrations of 4 chlorophenoxy-acid herbicides and 28 other herbicides. Maximum contaminant levels and minimum reporting levels for these compounds are shown on table 17. Because a new laboratory schedule with lower method detection limits and minimum reporting levels than past schedules was used, several samples had concentrations of some herbicides that exceeded the method detection limits or minimum reporting levels (table 18). Some of the samples listed in table 18 had concentrations that exceeded the method detection limit but were less than the minimum reporting level. One sample had an estimated concentration less than the method detection limit. Concentrations of atrazine in four samples ranged from 0.004 to $0.018 \mu \mathrm{g} / \mathrm{L}$. Estimated concentrations of desethyl atrazine in seven samples ranged from 0.002 to $0.010 \mu \mathrm{g} / \mathrm{L}$. Concentrations for desethyl atrazine are estimated because the analyses for desethyl atrazine demonstrates low recovery because of poor retention on the solidphase extraction column (Zaugg and others, 1995). The estimated concentration of metribuzin in one sample (MV-45) was $0.007 \mu \mathrm{g} / \mathrm{L}$. The estimated concentration of simazine in one sample (MV-06) was $0.029 \mu \mathrm{g} / \mathrm{L}$ and in another sample (MV-53) was $0.003 \mu \mathrm{g} / \mathrm{L}$. The estimated concentrations in table 18 need to be evaluated carefully because of variable performance (Zaugg and others, 1995). Samples from wells not listed in table 18 had concentrations less than the minimum reporting levels and method detection limits for all herbicides. Concentrations of herbicides not listed in table 18 were below the minimum reporting levels and method detection limits in all the samples.

\section{SUMMARY}

The USGS and the IDWR, in cooperation with the DOE, sampled 17 sites as part of a long-term project to monitor water quality of the Snake River Plain aquifer from the southern boundary of the Idaho National Engineering Laboratory to the Hagerman area. Water samples were collected and analyzed for selected radionuclides, stable isotopes, inorganic constituents, and organic com- 
Table 15. Maximum contaminant levels and minimum reporting levels of selected purgeable organic compounds in drinking water

[Analyses were performed by the U.S. Geological Survey National Water Quality Laboratory using an analytical method equivalent to U.S. Environmental Protection Agency method 524.2. Maximum contaminant levels were established pursuant to the recommendation of the U.S. Environmental Protection Agency $(1994 ; 1995$, p. 972) for community water systems and are included for comparison purposes only. Minimum reporting levels are from Timme (1995). Units are in micrograms per liter ( $\mu g / \mathrm{L})$. Symbols: $\omega^{\infty}$, maximum contaminant level has not been established or proposed; *, total trihalomethanes - which include bromoform. chlorodibromomethane, chloroform, and dichlorobromomethane -in community water systems senving 10,000 or more persons cannot exceed $100 \mu \mathrm{g} / \mathrm{L}$ (U.S. Environmental Protection Agency, 1995, p. 912). Abbreviations: MCL, maximum contaminant level; $M R L$, minimum reporting level]

\begin{tabular}{|c|c|c|c|c|c|}
\hline Compound & MCL & MRL & Compound & MCL & MRL \\
\hline Benzene & 5 & 0.2 & 1,3-Dichloropropane & "• & 0.2 \\
\hline Bromobenzene & $\bullet$ & .2 & 2,2-Dichloropropane & •• & .2 \\
\hline Bromochloromethane & $\bullet$ & .2 & cis-1,3-Dichloropropene & $\bullet$ & .2 \\
\hline Bromoform & * & .2 & trans-1,3-Dichloropropene & $\bullet$ & .2 \\
\hline Bromomethane & $\bullet$ & .2 & 1,1-Dichloropropene & $\bullet$ & .2 \\
\hline n-Butylbenzene & •• & .2 & Ethylbenzene & 700 & .2 \\
\hline sec-Butylbenzene & •• & .2 & Hexachlorobutadiene & $\bullet$ & .2 \\
\hline tert-Butylbenzene & $\bullet$ & .2 & Isopropylbenzene & $\bullet$ & .2 \\
\hline Carbon tetrachloride & 5 & .2 & p-Isopropyltoluene & $\bullet$ & .2 \\
\hline Chlorobenzene & 100 & .2 & Methylene chloride & 5 & .2 \\
\hline Chlorodibromomethane & * & .2 & Methyl tert-butylether & $\bullet$ & 1 \\
\hline Chloroethane & •• & .2 & Naphthalene & $\bullet$ & .2 \\
\hline 2-Chloroethylvinylether & •• & 1 & n-Propylbenzene & •• & .2 \\
\hline Chloroform & $*$ & .2 & Styrene & 100 & .2 \\
\hline Chloromethane & $\bullet$ & .2 & 1,1,1,2-Tetrachloroethane & -• & .2 \\
\hline 2-Chlorotoluene & .• & .2 & 1,1,2,2-Tetrachloroethane & $\bullet$ & .2 \\
\hline 4-Chlorotoluene & •. & .2 & Tetrachloroethylene & 5 & .2 \\
\hline 1,2-Dibromo-3-chloropropane & .2 & 1 & Toluene & 1,000 & .2 \\
\hline 1,2-Dibromoethane & .05 & .2 & 1,2,3-Trichlorobenzene & •• & .2 \\
\hline Dibromomethane & •• & .2 & 1,2,4-Trichlorobenzene & 70 & .2 \\
\hline 1,2-Dichlorobenzene & 600 & .2 & 1,1,1-Trichloroethane & 200 & .2 \\
\hline 1,3-Dichlorobenzene & 600 & .2 & 1,1,2-Trichloroethane & 5 & .2 \\
\hline 1,4-Dichlorobenzene & 75 & .2 & Trichloroethene & 5 & .2 \\
\hline Dichlorobromomethane & * & .2 & Trichlorofluoromethane & .• & .2 \\
\hline Dichlorodifluoromethane & .• & .2 & 1,2,3-Trichloropropane & •• & .2 \\
\hline 1,1-Dichloroethane & •• & .2 & 1,1,2-Trichloro 1,2,2-trifluoroethane & 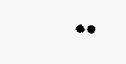 & .2 \\
\hline 1,2-Dichloroethane & 5 & .2 & 1,2,4-Trimethylbenzene & •• & .2 \\
\hline cis-1,2-Dichloroethene & 70 & .2 & 1,3,5-Trimethylbenzene & •• & .2 \\
\hline 1,1-Dichloroethene & 7 & .2 & Vinyl chloride & 2 & .2 \\
\hline trans-1,2-dichloroethene & 100 & .2 & Xylenes, total ortho, meta, and para & 10,000 & .2 \\
\hline 1,2-Dichloropropane & 5 & .2 & & & \\
\hline
\end{tabular}


Table 16. Maximum contaminant levels and minimum reporting levels of selected insecticides and gross polychlorinated compounds in drinking water

[Analyses were performed by the U.S. Geological Survey National Water Quality Laboratory. The maximum contaminant level was established pursuant to the recommendations of the U.S. Environmental Protection Agency (1995, p. 973-974) for community water systems and are included for comparison purposes only. Minimum reporting levels are from Timme (1995). Method detection limits are from Zaugg and others (1995). Units are in micrograms per liter. Symbols: $\bullet$, maximum contaminant level has not been established or proposed; ${ }^{*}$, samples analyzed using two different laboratory schedules with different minimum reporting levels. Abbreviations: MRL, minimum reporting level; MCL, maximum contaminant level; MDL, method detection limit]

\begin{tabular}{|c|c|c|c|c|c|}
\hline \multicolumn{6}{|c|}{ Carbamate insecticides } \\
\hline Insecticide & MCL & MRL & Insecticide & MCL & MRL \\
\hline Aldicarb & 3 & 0.5 & Methomyl & $\bullet$ & 0.5 \\
\hline *Carbaryl (Sevin) & 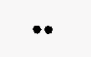 & .5 & 1-Naphthol & $\bullet$ & .5 \\
\hline *Carbofuran & 40 & .5 & Propham & $\bullet$ & .5 \\
\hline Methiocarb & $\bullet$ & .5 & Propoxur & $\bullet$ & .5 \\
\hline \multicolumn{6}{|c|}{ Organophosphate insecticides } \\
\hline Insecticide & $\mathrm{MCL}$ & MAL & Insecticide & $\mathrm{MCL}$ & MRL \\
\hline *Chlorpyrifos; Dursban & 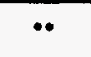 & 0.01 & *Malathion & $\bullet$ & 0.01 \\
\hline DEF & $\cdots$ & .01 & Methylparathion & $\bullet$ & .01 \\
\hline *Diazinon & $\bullet$ & .01 & Parathion & $\bullet$ & .01 \\
\hline *Di-Syston (Disulfoton) & $\bullet$ & .01 & *Phorate & $\bullet$ & .01 \\
\hline Ethion & $\cdots$ & .01 & Trithion & $\bullet$ & .01 \\
\hline *Fonofos & $\cdots$ & .01 & & & \\
\hline
\end{tabular}

\section{Organochlorine insecticides}

\begin{tabular}{lcclrr} 
Insecticide & MCL & MRL & Insecticide & MCL & MRL \\
\hline Aldrin &. & 0.01 & Heptachlor & 0.4 & 0.01 \\
Chlordane, technical & 2 & .1 & Heptachlor epoxide & .2 & .01 \\
DDD, p,p'- &.. & .01 & *Lindane & .2 & .01 \\
*DDE, p,p'- &.. & .01 & Methoxychlor, p,p'- & 40 & .01 \\
DDT, p,p'- &.$\cdot$ & .01 & Mirex &.. & .01 \\
*Dieldrin &.. & .01 & Perthane &.. & .1 \\
Endosulfan I &.. & .01 & Toxaphene & 3 & 1.0 \\
Endrin & 2 & .01 & & & \\
\hline
\end{tabular}

\section{Gross polychlorinated compounds}

Compound

Gross polychlorinated biphenyls (PCB's)

Gross polychlorinated naphthalenes (PCN's)
MCL

MRL

$\begin{array}{ll}0.5 & 0.1 \\ \bullet & 0.1\end{array}$


Table 16. Maximum contaminant levels and minimum reporting levels of selected insecticides and gross polychlorinated compounds in drinking water-Continued

\section{9 insectiddes with different MALs}

\begin{tabular}{|c|c|c|c|c|c|c|c|}
\hline Insecticide & MCL & MRL & MDL & Insecticide & MCL & MRL & MDL \\
\hline Azinphos methyl- & $\bullet$ & 0.038 & 0.001 & $\mathrm{HCH}$, alpha- & $\bullet$ & 0.007 & 0.002 \\
\hline *Carbaryl (Sevin) & $\bullet$ & .046 & .003 & *HCH, gamma- (Lindane) & 0.2 & .011 & .004 \\
\hline *Carbofuran & 40 & .013 & .003 & *Malathion & $\bullet$ & .010 & .005 \\
\hline *Chlorpyrifos & $\bullet$ & .005 & .004 & Parathion, ethyl- & $\bullet$ & .022 & .004 \\
\hline *DDE, p,p'- & $\bullet$ & .010 & .006 & Parathion, methyl- & $\bullet$ & .035 & .006 \\
\hline *Diazinon & $\bullet$ & .008 & .002 & Permethrine, cis- & $\bullet$ & .019 & .005 \\
\hline *Dieldrin & $\bullet$ & .008 & .001 & *Phorate & $\bullet$ & .011 & .002 \\
\hline *Disulfoton & $\cdots$ & .028 & .017 & Propargite I \& II & $\bullet$ & .006 & .013 \\
\hline Ethoprop & $\bullet$ & .012 & .003 & Terbufos & $\bullet$ & .012 & .013 \\
\hline *Fonofos & $\cdots$ & .008 & .003 & & & & \\
\hline
\end{tabular}

Table 17. Maximum contaminant levels and minimum reporting levels of chlorophenoxy-acid herbicides and other herbicides in drinking water

[Analyses were performed by the U.S. Geological Survey National Water Quality Laboratory. The maximum contaminant level was established pursuant to the recommendations of the U.S. Environmental Protection Agency (1995, p. 973, 974) for community water systems and are included for comparison purposes only. Minimum reporting levels are from Timme (1995). Method detection limils are from Zaugg and others (1995). Units are in micrograms per liter. Symbol: $\bullet$, maximum contaminant level has not been established or proposed. Abbreviations: MCL, maximum contaminant level; MRL, minimum reporting level; MDL, method detection limit]

\begin{tabular}{lcccccc}
\hline & \multicolumn{4}{c}{ Chlorophenoxy-acid herbicides } & & \\
Herbicide & MCL & MRL & Herbicide & MCL & MRL \\
\hline $2,4-D$ & 70 & 0.01 & Silvex & 50 & 0.01 \\
$2,4-D P$ & $\cdots$ & .01 & $2,4,5-T$ & $\cdots$ & .01 \\
\hline
\end{tabular}

\begin{tabular}{|c|c|c|c|c|c|c|c|}
\hline & & & Other & bicides & & & \\
\hline Herbicide & MCL & MAL & MDL & Herbicide & MCL & MRL & MDL \\
\hline Acetochlor & $\cdots$ & 0.009 & 0.002 & Molinate & 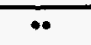 & 0.007 & 0.004 \\
\hline Alachlor & 2 & .009 & .002 & Napropamide & $\bullet$ & .010 & .003 \\
\hline Atrazine & 3 & .017 & .001 & Pebulate & $\bullet$ & .009 & .004 \\
\hline Atrazine, desethyl- & $\bullet$ & .007 & .002 & Pendimethalin & $\bullet$ & .018 & .004 \\
\hline Benfluralin & $\bullet$ & .013 & .002 & Prometon & $\bullet$ & .008 & .018 \\
\hline Butylate & $\bullet$ & .008 & .002 & Pronamide & $\bullet$ & .009 & .003 \\
\hline Cyanazine & $\bullet$ & .013 & .004 & Propachlor & $\bullet$ & .015 & .007 \\
\hline DCPA (Dacthal) & $\bullet$ & .004 & .002 & Propanil & $\bullet$ & .016 & .004 \\
\hline Diethylaniline & $\bullet$ & .006 & .003 & Simazine & 4 & .008 & .005 \\
\hline EPTC (Eptam) & $\bullet$ & .005 & .002 & Tebuthiuron & $\bullet$ & .015 & .010 \\
\hline Ethalfluralin & $\bullet$ & .013 & .004 & Terbacil & •• & .030 & .007 \\
\hline Linuron & •• & .039 & .002 & Thiobencarb & -• & .008 & .002 \\
\hline Metolachlor & $\bullet$ & .009 & .002 & Triallate & $\bullet$ & .008 & .001 \\
\hline Metribuzin & .. & .012 & .004 & Trifluralin & $\bullet$ & .012 & .002 \\
\hline
\end{tabular}


Table 18. Concentrations of herbicides in water from selected wells and springs, eastern Snake Fiver Plain

[See figure 2 for location of sites. Analyses were performed by the U.S. Geological Survey National Water Quality Laboratory. Units are in micrograms per liter. Symbols; <, concentration was less than the respective minimum reporting level; *, quality assurance sample (MV-44 is a replicate of MV-38). Concentrations for desethyl atrazine, metribuzin, and simazine were estimated and need to be evaluated carefully because of variable performance. Samples from wells not listed had concentrations below the minimum reporting levels and method detection limits for all herbicides and concentrations of herbicides not listed were below the minimum reporting levels and method detection limits in all samples]

\begin{tabular}{ccccr}
\hline Site identifier & Atrazine & $\begin{array}{l}\text { Desethyl } \\
\text { atrazine }\end{array}$ & Metribuzin & Simazine \\
\hline MV-05 & $<0.001$ & 0.003 & $<0.004$ & $<0.005$ \\
MV-06 & .018 & .010 & $<.004$ & .029 \\
MV-17 & $<.001$ & .002 & $<.004$ & $<.005$ \\
MV-31 & $<.001$ & .003 & $<.004$ & $<.005$ \\
MV-42 & .005 & .003 & $<.004$ & $<.005$ \\
MV-44* & .004 & .005 & .004 & $<.005$ \\
MV-45 & $<.017$ & $<.003$ & $<.004$ & $<.008$ \\
MV-53 & .006 & .006 & .003 \\
\hline
\end{tabular}

pounds. The samples were collected from 11 irrigation wells, 2 domestic wells, 2 stock wells, 1 spring, and 1 public-supply well. Two quality assurance samples also were collected and analyzed.

Concentrations of strontium-90 in all samples were less than the reporting level. Concentrations of tritium in 17 of the samples analyzed by the NWQL were greater than the reporting level, but none exceeded the maximum contaminant level for drinking water. All samples analyzed by ISU had concentrations of tritium less than the reporting level. Concentrations of dissolved gross alphaparticle radioactivity in two of the samples analyzed by the NWQL were greater than the reporting level; none exceeded the U.S. Environmental Protection Agency maximum contaminant level. Concentrations of dissolved gross beta-particle radioactivity in 16 samples analyzed by the NWQL were greater than the reporting level. Concentrations of total gross beta-particle radioactivity in 17 of the samples analyzed by ISU were equal to or greater than the reporting level. Concentrations of total cesium-137 were analyzed using gamma spectrometry and concentrations in all the samples were less than the reporting level.

Water samples were analyzed for concentrations of stable isotopes of $\mathrm{H}, \mathrm{O}, \mathrm{C}, \mathrm{S}$, and $\mathrm{N}$.
Relative isotopic ratios ranged from -139 to -128 permil for $\delta^{2} \mathrm{H},-18.10$ to -16.29 permil for $\delta^{18} \mathrm{O}$, -13.0 to -8.1 permil for $\delta^{13} \mathrm{C}, 5.5$ to 16.2 permil for $\delta^{34} \mathrm{~S}$, and 2.8 to 6.2 permil for $\delta^{15} \mathrm{~N}$.

All the samples contained one or more dissolved trace elements and common ions in concentrations greater than the minimum reporting levels. No concentration exceeded an established maximum contaminant level.

Concentrations of ammonia (as nitrogen) in six of the water samples were equal to or greater than the minimum reporting level. Concentrations of nitrite (as nitrogen) in all the samples were less than the minimum reporting level. Concentrations of nitrite plus nitrate (as nitrogen) in all the water samples were greater than the minimum reporting level. Concentrations of orthophosphate (as phosphorus) in 15 of the water samples were equal to or greater than the minimum reporting level. No nutrient concentration exceeded an established maximum contaminant level.

Concentrations of dissolved organic carbon in all the samples were greater than the minimum reporting level. Concentrations of anionic surfactants in all but one of the water samples were less than the minimum reporting level. No purgeable organic compounds, carbamate insecticides, organophosphate insecticides, organochlorine 
insecticides, gross PCB's, or gross PCN's were detected at concentrations exceeding their respective minimum reporting levels. Concentrations of some herbicides were greater than their method detection limits and minimum reporting levels, but none exceeded established maximum contaminant levels.

\section{SELECTED REFERENCES}

American Public Health Association and Water Pollution Control Federation, 1985, Standard methods for the examination of water and wastewater: Washington, D.C., American Public Health Association, 1,268 p.

American Society for Testing and Materials, 1992 , ASTM standards on precision and bias for various applications: Philadelphia, Pennsylvania, American Society for Testing and Materials Publication code number (PCN) 03511092-34, 478 p.

Bartholomay, R.C., Edwards, D.D., and Campbell, L.J., 1992, Radionuclides, inorganic constituents, organic compounds, and bacteria in water from selected wells and springs from the southern boundary of the Idaho National Engineering Laboratory to the Hagerman area, Idaho, 1990: U.S. Geological Survey Open-File Report 92-91 (DOE/ID 22102), $42 \mathrm{p}$.

-----1993, Radionuclides, inorganic constituents, organic compounds, and bacteria in water from selected wells and springs from the southem boundary of the Idaho National Engineering Laboratory to the Hagerman area, Idaho, 1991: U.S. Geological Survey Open-File Report 93-102 (DOE/ID-22108), $42 \mathrm{p}$.

-----1994a, Radionuclides, inorganic constituents, organic compounds, and bacteria in water from selected wells and springs from the southem boundary of the Idaho National Engineering Laboratory to the Hagerman area, Idaho, 1992: U.S. Geological Survey Open-File Report 94-76 (DOE/ID-22114), $41 \mathrm{p}$. ---1994b, Radionuclides, stable isotopes, inorganic constituents, and organic compounds in water from selected wells and springs from the southern boundary of the Idaho National Engineering Laboratory to the Hagerman area, Idaho, 1993: U.S. Geological Survey Open-File Report 94-503 (DOE/ID-22117), $35 \mathrm{p}$.

Bartholomay, R.C., Orr, B.R., Liszewski, M.J., and Jensen, R.G., 1995, Hydrologic conditions and distribution of selected radiochemical and chemical constituents in water, Snake River Plain aquifer, Idaho National Engineering Laboratory, Idaho, 1989 through 1991: U.S. Geological Survey Water-Resources Investigations Report 95-4175 (DOE/ID-22123), $47 \mathrm{p}$.

Bartholomay, R.C., Williams, L.M., and Campbell, L.J., 1995, Radionuclides, stable isotopes, inorganic constituents, and organic compounds in water from selected wells and springs from the southern boundary of the Idaho National Engineering Laboratory to the Hagerman Area, Idaho, 1994: U.S. Geological Survey Open-File Report 95-718 (DOE/ID22124), 37 p.

Claassen, H.C., 1982, Guidelines and techniques for obtaining water samples that accurately represent the water chemistry of an aquifer: U.S. Geological Survey Open-File Report 82-1024, 49 p.

Craig, Harmon, 1961, Isotopic variations in meteoric waters: Science, v. 133 , p. $1,702-1,703$.

Currie, L.A., 1984, Lower limits of detectiondefinition and elaboration of a proposed position for radiological effluent and environmental measurements: U.S. Nuclear Regulatory Commission NUREG/CR-4007, $139 \mathrm{p}$.

Faires, L.M., 1992, Methods of analysis by the U.S. Geological Survey National Water Quality Laboratory-determinations of metals in water by inductively coupled plasma-mass spectrometry: U.S. Geological Survey OpenFile Report 92-634, 28 p. 
Fishman, M.J., ed., 1993, Methods of analysis by the U.S. Geological Survey National Water Quality Laboratory-determination of inorganic and organic constituents in water and fluvial sediments: U.S. Geological Survey Open-File Report 93-125, 217 p.

Fishman, M.J., and Friedman, L.C., eds., 1989, Methods for determination of inorganic substances in water and fluvial sediments: U.S. Geological Survey Techniques of WaterResources Investigations, book 5, chap. A1, $545 \mathrm{p}$.

Friedman, L.C., and Erdmann, D.E., 1982, Quality assurance practices for the chemical and biological analyses of water and fluvial sediments: U.S. Geological Survey Techniques of Water-Resources Investigations, book 5 , chap. A6, $181 \mathrm{p}$.

Garabedian, S.P., 1986, Application of a parameter-estimation technique to modeling the regional aquifer underlying the eastem Snake River Plain, Idaho: U.S. Geological Survey Water-Supply Paper 2278, 60 p.

Goerlitz, D.F., and Brown, Eugene, 1972, Methods for analysis of organic substances in water: U.S. Geological Survey Techniques of WaterResources Investigations, book 5, chap. A3, $40 \mathrm{p}$.

Hardy, M.A., Leahy, P.P., and Alley, W.M., 1989, Well installation and documentation, and ground-water sampling protocols for the pilot National Water-Quality Assessment Program: U.S. Geological Survey Open-File Report 89-396, 36 p.

Idaho Department of Health and Welfare, 1989, Idaho regulations for public drinking water systems: Boise, Rules and Regulations of the Department of Health and Welfare, title 1, chapter 8 , not paginated.

Jones, B.E., 1987, Quality control manual of the U.S. Geological Survey's National Water Quality Laboratory: U.S. Geological Survey Open-File Report 87-457, 17 p.
Kjelstrom, L.C., 1992, Streamflow gains and losses in the Snake River and ground-water budgets for the Snake River Plain, Idaho and eastern Oregon: U.S. Geological Survey Open-File Report 90-172, 71 p.

Knobel, L.L., Orr, B.R., and Cecil, L.D., 1992, Summary of background concentrations of selected radiochemical and chemical constituents in ground water from the Snake River Plain aquifer, Idaho-estimated from an analysis of previously published data: Journal of the Idaho Academy of Science, v. 28, no. 1, p. 48-61.

Mann, L.J., 1986, Hydraulic properties of rock units and chemical quality of water for INEL-1 - a 10,365-foot deep test hole drilled at the Idaho National Engineering Laboratory, Idaho: U.S. Geological Survey Water-

Resources Investigations 'Report 86-4020 (DOE/LD-22070), 23 p.

1989, Tritium concentrations in flow from selected springs that discharge to the Snake River, Twin Falls-Hagerman area, Idaho: U.S. Geological Survey Water-Resources Investigations Report 89-456 (DOE/ID-22084), 20 p.

Mann, L.J., and Cecil, L.D., 1990, Tritium in ground water at the Idaho National Engineering Laboratory, Idaho: U.S. Geological Survey Water-Resources Investigations Report 90-4090 (DOE/ID-22090), 35 p.

Mann, L.J., and Knobel, L.L., 1990, Radionuclides, metals, and organic compounds in water, eastern part of A\&B Irrigation District, Minidoka County, Idaho: U.S. Geological Survey Open-File Report 90-191 (DOE/ID22087), 36 p.

Pittman, J.R., Jensen, R.G., and Fischer, P.R., 1988, Hydrologic conditions at the Idaho National Engineering Laboratory, 19821985: U.S. Geological Survey WaterResources Investigations Report 89-4008 (DOE/ID-22078), 73 p. 
Pritt, J.W., 1989, Quality assurance of sample containers and preservatives at the U.S. Geological Survey National Water Quality Laboratory, in Pederson, G.L., and Smith, M.M., compilers, U.S. Geological Survey Second National Symposium on Water QualityAbstracts of the technical sessions, Orlando, Fla., November 12-17, 1989: U.S. Geological Survey Open-File Report 89-409, 111 p.

Pritt, J.W., and Raese, J.W., eds., 1995, Quality assurance/quality control manual-National Water Quality Laboratory: U.S. Geological Survey Open-File Report 95-443, 35 p.

Stevens, H.H., Jr., Ficke, J.F., and Smoot, G.F., 1975, Water temperature-influential factors, field measurement, and data presentation: U.S. Geological Survey Techniques of WaterResources Investigations, book 5, chap. D1, $65 \mathrm{p}$.

Thatcher, L.L., Janzer, V.J., and Edwards, K.W., 1977, Methods for determination of radioactive substances in water and fluvial sediments: U.S. Geological Survey Techniques of Water-Resources Investigations, book 5, chap. A5, $95 \mathrm{p}$.

Timme, P.J., 1995, National Water Quality Laboratory, 1995 services catalog: U.S. Geological Survey Open-File Report 95-352, 120 p.

Toran, Laura, 1982, Isotopes in ground-water investigations: Groundwater, v. 20, no. 6 , p. $740-745$.

U.S. Environmental Protection Agency, 1994, EPA drinking water regulations and health advisories: U.S. Envimnmental Protection Agency, Office of Water, 822 R-94-001, 11 p.

U.S. Environmental Protection Agency, 1995, Protection of environment, Code of Federal Regulations 40: Office of the Federal Register, National Archives and Records Administration, parts 87 to $149,1,346 \mathrm{p}$.
Wegner, S.J., 1989, Selected water quality assurance data for water samples collected by the U.S. Geological Survey, Idaho National Engineering Laboratory, Idaho, 1980 to 1988: U.S. Geological Survey Water-Resources Investigations Report 89-4168 (DOE/ID22085), $91 \mathrm{p}$.

Wegner, S.J., and Campbell, L.J., 1991, Radionuclides, chemical constituents, and organic compounds in water from designated wells and springs from the southern boundary of the Idaho National Engineering Laboratory to the Hagerman area, Idaho, 1989: U.S. Geological Survey Open-File Report 91-232 (DOE/ID22098), 49 p.

Wershaw, R.L., Fishman, M.J., Grabbe, R.R., and Lowe, L.E., 1987, Methods for the determination of organic substances in water and fluvial sediments: U.S. Geological Survey Techniques of Water-Resources Investigations, book 5, chap. A3, $80 \mathrm{p}$.

Whitehead, R.L., 1986, Geohydrologic framework of the Snake River Plain, Idaho and eastem Oregon: U.S. Geological Survey Hydrologic Investigations Atlas HA-681, 3 sheets, scale 1:1,000,000.

Wood, W.W., 1981, Guidelines for collection and field analysis of ground-water samples for selected unstable constituents: U.S. Geological Survey Techniques of WaterResources Investigations, book 1, chap. D2, 24 p.

Zaugg, S.D., Sandstrom, M.W., Smith, S.G., and Fehlberg, K.M., 1995, Methods of analysis by the U.S. Geological Survey National Water Quality Laboratory-determination of pesticides in water by $\mathrm{C}-18$ solid-phase extraction and capillary-column gas chromatography/ mass spectrometry with selected-ion monitoring: U.S. Geological Survey OpenFile Report 95-181, 49 p. 